Article

\title{
Controls on Associations of Clay Minerals in Phanerozoic Evaporite Formations: An Overview
}

\author{
Yaroslava Yaremchuk ${ }^{1}$, Sofiya Hryniv ${ }^{1}$, Tadeusz Peryt ${ }^{2, *}$, Serhiy Vovnyuk ${ }^{1}$ and Fanwei Meng ${ }^{3}$ \\ 1 Institute of Geology and Geochemistry of Combustible Minerals of National Academy of Sciences of \\ Ukraine, 3a Naukova St., 79060 Lviv, Ukraine; slava.yaremchuk@gmail.com (Y.Y.); \\ sophia_hryniv@ukr.net (S.H.); serhiy.vovnyuk@gmail.com (S.V.) \\ 2 Polish Geological Institute-National Research Institute, Rakowiecka 4, 00-975 Warszawa, Poland \\ 3 State Key Laboratory for Paleobiology and Stratigraphy, Nanjing Institute of Geology and Palaeontology \\ Chinese Academy of Sciences, Beijing East Road 39\#, Nanjing 210021, China; fwmeng@nigpas.ac.cn \\ * Correspondence: tadeusz.peryt@pgi.gov.pl
}

Received: 19 September 2020; Accepted: 30 October 2020; Published: 1 November 2020

\begin{abstract}
Information on the associations of clay minerals in Upper Proterozoic and Phanerozoic marine evaporite formations suggests that cyclic changes in the $\left(\mathrm{SO}_{4}\right.$-rich and Ca-rich) chemical type of seawater during the Phanerozoic could affect the composition of associations of authigenic clay minerals in marine evaporite deposits. The vast majority of evaporite clay minerals are authigenic. The most common are illite, chlorite, smectite and disordered mixed-layer illite-smectite and chlorite-smectite; all the clay minerals are included regardless of their quantity. Corrensite, sepiolite, palygorskite and talc are very unevenly distributed in the Phanerozoic. Other clay minerals (perhaps with the exception of kaolinite) are very rare. Evaporites precipitated during periods of $\mathrm{SO}_{4}$-rich seawater type are characterized by both a greater number and a greater variety of clay minerals-smectite and mixed-layer minerals, as well as Mg-corrensite, palygorskite, sepiolite, and talc, are more common in associations. The composition of clay mineral association in marine evaporites clearly depends on the chemical type of seawater and upon the brine concentration in the evaporite basin. Along with increasing salinity, aggradational transformations of clay minerals lead to the ordering of their structure and, ideally, to a decrease in the number of minerals. In fact, evaporite deposits of higher stages of brine concentration often still contain unstable clay minerals. This is due to the intense simultaneous volcanic activity that brought a significant amount of pyroclastic material into the evaporite basin; intermediate products of its transformation (in the form of swelling minerals) often remained in the deposits of the potassium salt precipitation stage.
\end{abstract}

Keywords: clay minerals; marine evaporites; seawater chemical type; pyroclastic material; Phanerozoic

\section{Introduction}

Authigenic clay minerals of marine evaporites can be used to identify the dependence of clay mineral association of evaporite deposits on the chemical type of seawater. Allogenic aluminosilicates, brought into a hypersaline environment of an evaporite basin as terrigenous and pyroclastic material, were destroyed or transformed, giving rise to authigenic, neoformed and transformed clay minerals [1,2]. It is assumed that the vast majority of clay minerals of evaporites are authigenic [3-5]. The previous study of clays indicated that from Archean to recent times their potassium content was decreasing, and the sodium content was increasing from the Archean to Late Mesozoic, and then was decreasing [6,7]. From the Proterozoic to the Recent, the illite-chlorite association in sedimentary rocks is more complex by the appearance of kaolinite and swelling minerals. Already in Mesozoic, the amount of kaolinite, 
smectite, and mixed-layer minerals is equal to that of illite and chlorite $[7,8]$. The estimation of relative distribution of kaolinite, palygorskite, smectite, and corrensite-like minerals, as well as the total carbonate and dolomite content, is presented in [9], with further detailing of the evolution of mineral composition of layered silicates on continents and in the Atlantic Ocean from Precambrian to modern time [10].

The concept of cyclic changes of seawater composition based on the analysis of the mineral composition of marine limestones and potassium salts [11-13] was confirmed by the study of fluid inclusions in halite, which indicated that the chemical type of seawater composition during the Phanerozoic was changing from $\mathrm{SO}_{4}$-rich to Ca-rich and vice versa [14-18]. The purpose of our study was to reveal if there were secular changes in the distribution of clay minerals of marine evaporites during the Phanerozoic and to find out the role and significance of the global (seawater chemistry, regularities of transformation processes) and local (volcanic material contribution) factors on the formation of associations of authigenic clay minerals (both neoformed and transformed) in evaporite deposits.

\section{Material}

Our research is based on the published results of clay mineral studies of the Phanerozoic and Upper Proterozoic evaporites, from both the pelitic fraction of water-insoluble residue and clay bands in evaporites. The data are taken from 74 publications concerning 38 Phanerozoic marine evaporite formations from various continents. Twenty-three formations were formed during the periods of $\mathrm{SO}_{4}$-rich seawater: 3 in Neogene, 4 in Paleogene, 4 in Triassic, 7 in Permian, 3 in Pennsylvanian, and 2 in late Proterozoic times. Fifteen formations were formed during the periods of Ca-rich type of seawater-2 in Cretaceous, 2 in Jurassic, 2 in Mississippian, 5 in Devonian, 2 in Silurian, and 2 in Cambrian times. The largest number of studied formations are the Permian (7) and Devonian (5); there are no data for the Ordovician. All considered evaporite formations are located on the continents of the Northern Hemisphere (Table 1, Figure 1).

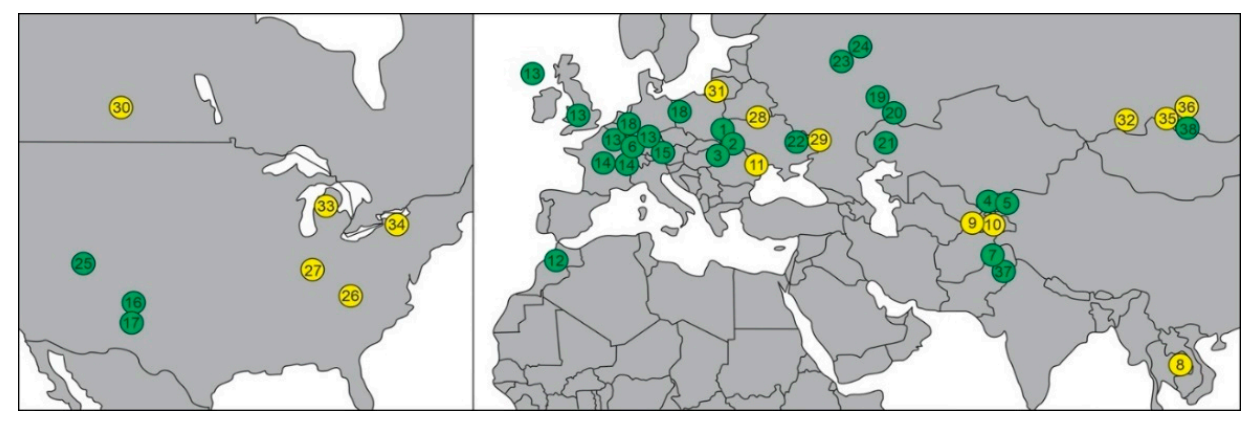

Figure 1. The location of Phanerozoic marine evaporite formations analysed (green colour indicates formations deposited from seawater of $\mathrm{SO}_{4}$-rich chemical type, and yellow colour indicates formations deposited from seawater of Ca-rich chemical type). Neogene: 1, 2, 3-Carpathian Foredeep, Ukraine, Poland; Transcarpathian Depression, Ukraine; Paleogene: 4, 5-Fergana Basin, Uzbekistan; 6-Alsace, France; 7-Bahadur Khel Formation, Pakistan; Cretaceous: 8-Maha Sarakham Formation, Thailand; 9-SW branches of Hissar Range, Tajikistan; Jurassic: 10-SW branches of Hissar Range, Tajikistan; 11-Foredobrudzha, Ukraine; Triassic: 12-Atlas-Oran Basin, Western Moroccan Basin, North Africa; 13, 14-Keuper, Muschelkalk, Germany, Great Brittain, France; 15-Buntsandstein, German Basin; Permian: 16, 17-Delaware Basin, USA; 18-Southern Permian Basin, Zechstein, Poland, Germany; 19, 20,-Uralian Foredeep, Russia; 21-Uralian Foredeep, Russia, Caspian Depression, Kazakhstan; 22-Donbas, Ukraine; Carboniferous: 23, 24-Eastern European Platform, Russia; 25-Paradox Basin, USA; 26-Saltville Basin, USA; 27-St. Louis Formation, USA; Devonian: 28-Prypiat Depression, Belarus; 29-Dnipro-Donets Depression, Ukraine; 30-Saskatchewan Basin Canada; 31-Baltic Syneclise; 32-Central Tuva deep, Russia; Silurian: 33-Michigan Basin, USA; 34-Appalachian Basin, USA; Cambrian: 35, 36-Irkutsk Amphitheatre, Russia; Upper Neoproterozoic: 37-Salt Range, Pakistan; 38-Irkutsk Amphitheatre, Russia. 
Table 1. Clay mineral association in Phanerozoic marine evaporite formations were analysed in this study. Minerals: ch—chlorite, ch* $\mathrm{swelling}^{*} \mathrm{chlorite}$, ch-s—chlorite-smectite, ch-v—chlorite-vermiculite, co-corrensite, hb-v-hydrobiotite-vermiculite, i-illite, i-s-illite-smectite, k-kaolinite, p-palygorskite, $\mathrm{s}$ - smectite, se-serpentine, sp-sepiolite, $\mathrm{t}$ - talc, $\mathrm{t}$-s—-talc-smectite.

\begin{tabular}{|c|c|c|c|c|c|c|c|}
\hline \multirow{2}{*}{$\begin{array}{l}\text { Formation } \\
\text { Number }\end{array}$} & \multirow[t]{2}{*}{ System, Series } & \multirow{2}{*}{$\begin{array}{l}\text { Stage, Formation, Suite, } \\
\text { Horizon }\end{array}$} & \multirow[t]{2}{*}{ Basin, Deposit, Country } & \multicolumn{3}{|c|}{$\begin{array}{l}\text { Clay Minerals in Evaporites Deposited } \\
\text { at Different Concentration Stages }\end{array}$} & \multirow[t]{2}{*}{ Ref. } \\
\hline & & & & Sulfate-Carbonate & Halite & Potassium Salts & \\
\hline \multirow{7}{*}{1} & \multirow{7}{*}{ Neogene, Miocene ${ }^{2}$} & \multirow{5}{*}{ Badenian, Tyras Suite } & \multirow{2}{*}{$\begin{array}{l}\text { Carpathian Foredeep, Bil'che-Volytsya zone, } \\
\text { Ukraine }\end{array}$} & $\mathrm{ch}, \mathrm{s}, \mathrm{i}$ & & & [19] \\
\hline & & & & s, i, ch, ch-s, i-s & & & {$[20,21]$} \\
\hline & & & $\begin{array}{l}\text { Carpathian Foredeep, Kalush-Holyn' } \\
\text { potassium salt deposit, Ukraine }\end{array}$ & & & $\mathrm{i}, \mathrm{ch}$ & {$[22,23]$} \\
\hline & & & Carpathian Foredeep, Hrynivka area, Ukraine & & $\begin{array}{l}\text { s, i, ch, ch-s, i-s, } \\
\text { co }\end{array}$ & & [24] \\
\hline & & & $\begin{array}{l}\text { Carpathian Foredeep, Silets'-Stupnytsya area, } \\
\text { Ukraine }\end{array}$ & & $\begin{array}{l}\mathrm{i}, \mathrm{ch}, \mathrm{ch}-\mathrm{s}, \mathrm{i}-\mathrm{s}, \\
\text { co }\end{array}$ & & [25] \\
\hline & & $\begin{array}{l}\text { Badenian, Wieliczka } \\
\text { Formation }\end{array}$ & $\begin{array}{l}\text { Carpathian Foredeep, Wieliczka and Bochnia } \\
\text { rock salt deposits, Poland }\end{array}$ & & s, i-s, ch-s, i, k & & {$[26,27]$} \\
\hline & & $\begin{array}{l}\text { Badenian, Krzyża- nowice } \\
\text { Formation }\end{array}$ & $\begin{array}{l}\text { Carpathian Foredeep, Badenian gypsum, } \\
\text { Poland }\end{array}$ & $\mathrm{i}, \mathrm{i}-\mathrm{s}, \mathrm{k}$ & & & [28] \\
\hline 2 & Neogene, Miocene ${ }^{2}$ & Badenian, Tereblya suite & Transcarpathian Depression, Ukraine & & $\mathrm{i}, \mathrm{ch}, \mathrm{i}-\mathrm{s}$ & & [29-31] \\
\hline \multirow{2}{*}{3} & \multirow{2}{*}{ Neogene, Miocene ${ }^{2}$} & \multirow{2}{*}{$\begin{array}{l}\text { Eger-Eggenburgian, } \\
\text { Vorotyshcha Suite }\end{array}$} & $\begin{array}{l}\text { Carpathian Foredeep, Stebnyk potassium salt } \\
\text { deposit, Ukraine }\end{array}$ & & & $\mathrm{i}, \mathrm{ch}$ & {$[22,32]$} \\
\hline & & & $\begin{array}{l}\text { Carpathian Foredeep, Boryslav, Strutyn areas, } \\
\text { Ukraine }\end{array}$ & & $i, c h, i-s$ & & [25] \\
\hline 4 & Paleogene, Oligocene ${ }^{2}$ & Suzak (upper part) & Fergana Basin, Uzbekistan & $\mathrm{sp}, \mathrm{s}, \mathrm{i}$ & & & {$[33,34]$} \\
\hline 5 & Paleogene, Oligocene ${ }^{2}$ & & $\begin{array}{l}\text { Fergana Basin, Kamish-Kurgan rock salt } \\
\text { deposit, Uzbekistan }\end{array}$ & & $\mathrm{s}, \mathrm{ch}$ & & [35] \\
\hline \multirow{2}{*}{6} & \multirow{2}{*}{ Paleogene, Oligocene ${ }^{2}$} & \multirow{2}{*}{ Sanuasian } & $\begin{array}{l}\text { Rhein Graben, Alsatian potassium salt deposit, } \\
\text { France }\end{array}$ & & & $\mathrm{i}$ & [32] \\
\hline & & & $\begin{array}{l}\text { Mulhouse Horst, Alsatian potassium salt } \\
\text { deposit, France }\end{array}$ & & & i, i-s & [36] \\
\hline
\end{tabular}


Table 1. Cont.

\begin{tabular}{|c|c|c|c|c|c|c|c|}
\hline \multirow{2}{*}{$\begin{array}{l}\text { Formation } \\
\text { Number }\end{array}$} & \multirow[t]{2}{*}{ System, Series } & \multirow{2}{*}{$\begin{array}{l}\text { Stage, Formation, Suite, } \\
\text { Horizon }\end{array}$} & \multirow[t]{2}{*}{ Basin, Deposit, Country } & \multicolumn{3}{|c|}{$\begin{array}{l}\text { Clay Minerals in Evaporites Deposited } \\
\text { at Different Concentration Stages }\end{array}$} & \multirow[t]{2}{*}{ Ref. } \\
\hline & & & & Sulfate-Carbonate & Halite & Potassium Salts & \\
\hline 7 & Paleogene, Eocene (lower) ${ }^{2}$ & $\begin{array}{l}\text { Bahadur Khel Salt } \\
\text { Formation }\end{array}$ & Kohat-Potwar Plateau, Pakistan & & $\begin{array}{l}\mathrm{ch}^{*}, \mathrm{ch}-\mathrm{s}, \mathrm{k}, \mathrm{i} \\
\mathrm{ch}\end{array}$ & & [37] \\
\hline 8 & Cretaceous-Paleogene $^{3}$ & $\begin{array}{l}\text { Maha Sarakham } \\
\text { Formation }\end{array}$ & K-118 borehole, NE Thailand & & $\mathrm{i}, \mathrm{ch}, \mathrm{ch}-\mathrm{s}$ & $\mathrm{i}, \mathrm{ch}, \mathrm{ch}-\mathrm{s}$ & [38] \\
\hline 9 & Lower Cretaceous $^{3}$ & Almurad Suite & $\begin{array}{c}\text { SW branches of Hissar Range, Karabil, } \\
\text { Tajikistan }\end{array}$ & & $\mathrm{i}, \mathrm{ch}$ & & [39] \\
\hline \multirow{3}{*}{10} & \multirow{3}{*}{ Upper Jurassic $^{3}$} & \multirow{3}{*}{$\begin{array}{l}\text { Kimmeridgian-Tithonian, } \\
\text { Gaurdak Suite }\end{array}$} & $\begin{array}{c}\text { SW branches of Hissar Range, Tubegatan, } \\
\text { Tajikistan }\end{array}$ & & $\mathrm{i}, \mathrm{ch}$ & & [39] \\
\hline & & & $\begin{array}{l}\text { SW branches of Hissar Range, Kizil-Mazar, } \\
\text { Ak-Bash, Tajikistan }\end{array}$ & & $\mathrm{i}, \mathrm{ch}, \mathrm{k}$ & $\mathrm{i}, \mathrm{ch}, \mathrm{k}$ & [39] \\
\hline & & & Tajik Depression, Tut-Bulak, Tajikistan & $\mathrm{i}, \mathrm{k}$ & $\mathrm{i}, \mathrm{ch}, \mathrm{sp}, \mathrm{k}$ & & [39] \\
\hline \multirow{2}{*}{11} & \multirow{2}{*}{ Upper Jurassic $^{3}$} & \multirow{2}{*}{$\begin{array}{l}\text { Kimmeridgian, Kongaz } \\
\text { Suite }\end{array}$} & \multirow{2}{*}{ Foredobrudzha, Ukraine } & & $\mathrm{i}, \mathrm{ch}, \mathrm{s}$ & & [40] \\
\hline & & & & & i, ch, ch-s, i-s & & [41] \\
\hline \multirow{3}{*}{12} & \multirow{3}{*}{ Upper Triassic $^{2}$} & & North Africa & $\mathrm{i}, \mathrm{ch}, \mathrm{co}, \mathrm{k}$ & & & [42] \\
\hline & & & Atlas-Oran Basin Demnate, Morocco & i, ch & $\mathrm{i}, \mathrm{ch}$ & & [43] \\
\hline & & & Western Moroccan Basin, Morocco & & $\mathrm{s}, \mathrm{i}, \mathrm{ch}^{*}, \mathrm{sp}, \mathrm{p}$ & & [43] \\
\hline \multirow{8}{*}{13} & \multirow{8}{*}{ Upper Triassic $^{2}$} & \multirow{8}{*}{$\begin{array}{l}\text { Carnian and Norian, } \\
\text { Keuper }\end{array}$} & Stuttgart, Germany & $\mathrm{i}, \mathrm{ch}, \mathrm{co}$ & & & [44] \\
\hline & & & Germany & i, co & & & [45] \\
\hline & & & \multirow{2}{*}{ Midlands, England } & $\mathrm{sp}, \mathrm{i}$ & & & [46] \\
\hline & & & & $\mathrm{i}, \mathrm{ch}^{*}$ & & & [47] \\
\hline & & & South Devon Coast, England & $\mathrm{i}, \mathrm{ch}, \mathrm{i}-\mathrm{s}, \mathrm{sp}, \mathrm{p}$ & & & [48] \\
\hline & & & Western Approaches, Great Britain & $\mathrm{i}$ & $\mathrm{i}, \mathrm{ch}, \mathrm{co}$ & & [48] \\
\hline & & & \multirow{2}{*}{ Lorraine Basin, France } & i, ch, hb-v & & & [36] \\
\hline & & & & $\mathrm{i}, \mathrm{ch}, \mathrm{co}, \mathrm{ch}-\mathrm{s}$ & $\mathrm{i}, \mathrm{ch}, \mathrm{co}$ & & [43] \\
\hline \multirow{2}{*}{14} & \multirow{2}{*}{ Upper, Middle Triassic ${ }^{2}$} & \multirow{2}{*}{ Keuper, Muschelkalk } & Jurassic Basin, France & $\mathrm{i}, \mathrm{ch}, \mathrm{co}, \mathrm{ch}-\mathrm{s}$ & & & {$[43,49]$} \\
\hline & & & Paris Basin, France & $\mathrm{i}, \mathrm{ch}, \mathrm{co}$ & & & [43] \\
\hline
\end{tabular}


Table 1. Cont.

\begin{tabular}{|c|c|c|c|c|c|c|c|}
\hline \multirow{2}{*}{$\begin{array}{l}\text { Formation } \\
\text { Number }\end{array}$} & \multirow[t]{2}{*}{ System, Series } & \multirow{2}{*}{$\begin{array}{l}\text { Stage, Formation, Suite, } \\
\text { Horizon }\end{array}$} & \multirow[t]{2}{*}{ Basin, Deposit, Country } & \multicolumn{3}{|c|}{$\begin{array}{l}\text { Clay Minerals in Evaporites Deposited } \\
\text { at Different Concentration Stages }\end{array}$} & \multirow[t]{2}{*}{ Ref. } \\
\hline & & & & Sulfate-Carbonate & Halite & Potassium Salts & \\
\hline 15 & Lower Triassic $^{2}$ & Buntsandstein & German Basin, Eastern Bavaria, Germany & i, ch, co, ch-s & & & [50] \\
\hline 16 & Upper Permian $^{2}$ & Castile Formation & Delaware Basin, NM, USA & $\mathrm{sp}, \mathrm{s}, \mathrm{ch}$ & & & [51] \\
\hline \multirow[b]{2}{*}{17} & \multirow[b]{2}{*}{ Upper Permian $^{2}$} & \multirow[b]{2}{*}{ Salado Formation } & \multirow[b]{2}{*}{ Delaware Basin, NM, USA } & $\mathrm{s}, \mathrm{i}, \mathrm{ch}, \mathrm{t}$ & & $\mathrm{i}, \mathrm{ch}-\mathrm{s}, \mathrm{ch}, \mathrm{t}, \mathrm{t}-\mathrm{s}$ & [51] \\
\hline & & & & & & $\begin{array}{l}\text { ch-s, ch-v, co, i, } \\
\text { ch }\end{array}$ & [52] \\
\hline \multirow{6}{*}{18} & \multirow{6}{*}{ Upper Permian $^{2}$} & \multirow{6}{*}{ Zechstein } & Southern Permian Basin, Western Poland & & $\mathrm{s}, \mathrm{i}, \mathrm{ch}, \mathrm{p}, \mathrm{ch}-\mathrm{s}$ & & [53] \\
\hline & & & \multirow{5}{*}{ Southern Permian Basin, Western Germany } & $\begin{array}{l}\mathrm{i}, \mathrm{ch}, \mathrm{t}, \mathrm{s}, \mathrm{ch}-\mathrm{s}, \mathrm{i}-\mathrm{s}, \\
\text { co }\end{array}$ & $\mathrm{i}, \mathrm{ch}, \mathrm{co}$ & i, ch & {$[54,55]$} \\
\hline & & & & $\mathrm{ch}, \mathrm{t}$ & $\mathrm{i}, \mathrm{ch}$ & $\begin{array}{l}\text { i, ch, co, ch-s, t, } \\
\text { sp }\end{array}$ & {$[56-58]$} \\
\hline & & & & & $\mathrm{co}, \mathrm{i}, \mathrm{ch}, \mathrm{t}$ & ch, i & [59] \\
\hline & & & & & co, ch, i, t & $\mathrm{co}, \mathrm{ch}, \mathrm{i}$ & [58] \\
\hline & & & & $\mathrm{t}, \mathrm{co}, \mathrm{s}, \mathrm{i}, \mathrm{ch}$ & & & [60] \\
\hline \multirow[b]{2}{*}{19} & \multirow[b]{2}{*}{ Middle Permian $^{2}$} & \multirow[b]{2}{*}{ Kazan } & Uralian Foredeep, Russia & $\mathrm{i}, \mathrm{ch}, \mathrm{co}, \mathrm{ch}-\mathrm{s}$ & & & [61] \\
\hline & & & $\begin{array}{l}\text { Uralian Foredeep, Buguruslan-Sorochinsk } \\
\text { Basin, Russia }\end{array}$ & ch, ch-s, co, i, s & $\mathrm{i}, \mathrm{ch}$ & & [4] \\
\hline 20 & Middle Permian $^{2}$ & $\begin{array}{l}\text { Ufa, Kazan, Tatar (lower } \\
\text { part) }\end{array}$ & Uralian Foredeep, Southern part, Russia & $\mathrm{s}, \mathrm{i}, \mathrm{co}, \mathrm{ch}$ & & & [62] \\
\hline \multirow{3}{*}{21} & \multirow{3}{*}{ Lower Permian ${ }^{2}$} & \multirow{3}{*}{ Kungurian } & $\begin{array}{l}\text { Uralian Foredeep, Upper Kama potassium } \\
\text { salts deposit, Russia }\end{array}$ & & & i, ch & [63] \\
\hline & & & \multirow{2}{*}{$\begin{array}{l}\text { Caspian Depression, Inder potassium salts } \\
\text { deposit, Kazakhstan }\end{array}$} & & & $\mathrm{i}, \mathrm{ch}$ & [32] \\
\hline & & & & & & $\begin{array}{l}\text { s, i, ch, co, ch-s, } \\
\text { ch-v, se, t }\end{array}$ & [4] \\
\hline \multirow{3}{*}{22} & \multirow{3}{*}{ Lower Permian ${ }^{2}$} & $\begin{array}{l}\text { Sakmarian, Kramatorsk } \\
\text { Suite }\end{array}$ & Dnipro-Donets Depression, Ukraine & & & i, ch, i-s, ch-s & {$[64,65]$} \\
\hline & & \multirow{2}{*}{$\begin{array}{l}\text { Asselian, Mykytiv and } \\
\text { Kartamysh Suits }\end{array}$} & Dnipro-Donets Depression, Ukraine & i, ch, i-s, ch-s, k & $\mathrm{i}, \mathrm{ch}, \mathrm{i}-\mathrm{s}, \mathrm{k}$ & & [64] \\
\hline & & & Western Donbas, Ukraine & $\mathrm{i}, \mathrm{ch}, \mathrm{co}$ & $\mathrm{i}, \mathrm{ch}, \mathrm{co}$ & & [66] \\
\hline
\end{tabular}


Table 1. Cont

\begin{tabular}{|c|c|c|c|c|c|c|c|}
\hline \multirow{2}{*}{$\begin{array}{l}\text { Formation } \\
\text { Number }\end{array}$} & \multirow[t]{2}{*}{ System, Series } & \multirow{2}{*}{$\begin{array}{l}\text { Stage, Formation, Suite, } \\
\text { Horizon }\end{array}$} & \multirow[t]{2}{*}{ Basin, Deposit, Country } & \multicolumn{3}{|c|}{$\begin{array}{l}\text { Clay Minerals in Evaporites Deposited } \\
\text { at Different Concentration Stages }\end{array}$} & \multirow[t]{2}{*}{ Ref. } \\
\hline & & & & Sulfate-Carbonate & Halite & Potassium Salts & \\
\hline 23 & $\begin{array}{l}\text { Carboniferous }{ }^{3} ; \\
\text { Pennsylvanian }^{2}\end{array}$ & Gzhelian, Kasimovian & Eastern European Platform, Russia & $\mathrm{p}, \mathrm{sp}, \mathrm{s}$ & & & {$[34,67]$} \\
\hline 24 & $\begin{array}{l}\text { Carboniferous }{ }^{3} ; \\
\text { Pennsylvanian }{ }^{2}\end{array}$ & Kashir horizon & Eastern European Platform, Russia & $\mathrm{p}, \mathrm{sp}, \mathrm{i}$ & & & {$[34,67]$} \\
\hline 25 & $\begin{array}{l}\text { Carboniferous }{ }^{3} ; \\
\text { Pennsylvanian }\end{array}$ & Hermosa Formation & Paradox Basin, UT, USA & $\mathrm{i}, \mathrm{ch}$ & co & & [51] \\
\hline \multirow{2}{*}{26} & \multirow{2}{*}{$\begin{array}{l}\text { Carboniferous }^{3} ; \\
\text { Missisippian }^{3}\end{array}$} & \multirow{2}{*}{ Maccrady Formation } & Saltville Basin, Cumberland Plateau, VA, USA & & $\mathrm{i}, \mathrm{ch}$ & & [68] \\
\hline & & & Saltville Basin, Cumberland Plateau, TN, USA & $\mathrm{s}, \mathrm{i}, \mathrm{co}, \mathrm{ch}-\mathrm{v}$ & & & {$[69,70]$} \\
\hline \multirow{2}{*}{27} & \multirow{2}{*}{$\begin{array}{l}\text { Carboniferous } \\
\text { Missisippian }^{3}\end{array}$} & \multirow{2}{*}{ St. Louis Formation } & Southwestern Indiana, IN, USA & i, ch, i-s & & & [71] \\
\hline & & & IN, USA & i, ch & & & [52] \\
\hline \multirow{6}{*}{28} & \multirow{6}{*}{ Upper Devonian $^{3}$} & \multirow{6}{*}{$\begin{array}{l}\text { Famennian, Maksakov } \\
\text { Suite }\end{array}$} & \multirow{5}{*}{$\begin{array}{l}\text { Prypiat Depression, Starobin potassium salt } \\
\text { deposit, Belarus }\end{array}$} & & & i & [72-74] \\
\hline & & & & & & $\mathrm{s}, \mathrm{ch}$ & [75] \\
\hline & & & & & & $\mathrm{i}, \mathrm{ch}$ & {$[76]$} \\
\hline & & & & & & i, ch, ch-s, s & [77] \\
\hline & & & & & & i, ch, ch-s, ch-v & {$[78,79]$} \\
\hline & & & $\begin{array}{l}\text { Prypiat Depression (western part), Petrikov } \\
\text { potassium salt deposit, Belarus }\end{array}$ & & & $\mathrm{i}, \mathrm{ch}, \mathrm{i}-\mathrm{s}$ & {$[80,81]$} \\
\hline \multirow{4}{*}{29} & \multirow{4}{*}{ Upper Devonian ${ }^{3}$} & Famennian, Frasnian & Dnipro-Donets Depression, Ukraine & & $\mathrm{i}, \mathrm{ch}$ & & [82] \\
\hline & & Famennian & Dnipro-Donets Depression, Ukraine & & ch, i, s & & [65] \\
\hline & & \multirow{2}{*}{ Frasnian } & \multirow{2}{*}{ Dnipro-Donets Depression, Ukraine } & & $\mathrm{i}, \mathrm{ch}, \mathrm{k}$ & & [64] \\
\hline & & & & & $\begin{array}{l}\text { i, ch, i-s, s, k, } \\
\text { ch-s }\end{array}$ & & [65] \\
\hline 30 & Middle Devonian $^{3}$ & Prairie Formation & Saskatchewan Basin, Canada & & & $\mathrm{ch}, \mathrm{i}, \mathrm{sp}, \mathrm{s}, \mathrm{ch}-\mathrm{s}$ & [83] \\
\hline 31 & Middle Devonian $^{3}$ & $\begin{array}{c}\text { Eifelian, Tartu and Narva } \\
\text { horizons }\end{array}$ & Baltic Syneclise & $\mathrm{i}, \mathrm{ch}, \mathrm{co}$ & & & {$[4,62]$} \\
\hline
\end{tabular}


Table 1. Cont

\begin{tabular}{|c|c|c|c|c|c|c|c|}
\hline \multirow{2}{*}{$\begin{array}{l}\text { Formation } \\
\text { Number }\end{array}$} & \multirow{2}{*}{ System, Series } & \multirow{2}{*}{$\begin{array}{l}\text { Stage, Formation, Suite, } \\
\text { Horizon }\end{array}$} & \multirow{2}{*}{ Basin, Deposit, Country } & \multicolumn{3}{|c|}{$\begin{array}{l}\text { Clay Minerals in Evaporites Deposited } \\
\text { at Different Concentration Stages }\end{array}$} & \multirow{2}{*}{ Ref. } \\
\hline & & & & Sulfate-Carbonate & Halite & Potassium Salts & \\
\hline 32 & Middle Devonian ${ }^{3}$ & $\begin{array}{l}\text { Upper Eifelian, lower } \\
\text { Givetian, Ihedushin-golsk } \\
\text { Suite }\end{array}$ & $\begin{array}{c}\text { Central Tuva deep, Tuz-Tag rock salt deposit, } \\
\text { Russia }\end{array}$ & & $c h, i$ & & [84] \\
\hline 33 & $\begin{array}{c}\text { Silurian (upper } \\
\text { Wenlock-Pridoli) }^{3}\end{array}$ & Salina Formation & Michigan Basin, MI, USA & $\mathrm{i}, \mathrm{ch}$ & $\mathrm{i}, \mathrm{ch}$ & & [85] \\
\hline \multirow{2}{*}{34} & \multirow{2}{*}{ Silurian (upper Wenlock) ${ }^{3}$} & \multirow{2}{*}{ Vernon Formation } & \multirow{2}{*}{ Appalachian Basin, Retsof deposit, NY, USA } & & $\mathrm{i}, \mathrm{ch}$ & & [86] \\
\hline & & & & & $\mathrm{i}, \mathrm{ch}, \mathrm{t}$ & & {$[51,87]$} \\
\hline 35 & Lower, Middle Cambrian $^{3}$ & Angara Suite & $\begin{array}{c}\text { East Siberian Platform, Irkutsk Amphitheatre, } \\
\text { Russia }\end{array}$ & & $\mathrm{t}, \mathrm{i}, \mathrm{ch}$ & $\mathrm{t}, \mathrm{i}, \mathrm{ch}$ & [88] \\
\hline 36 & Lower, Cambrian $^{3}$ & $\begin{array}{l}\text { Aldan, Lena; Motsk, } \\
\text { Usolsk, Belsk and Angara } \\
\text { suites }\end{array}$ & $\begin{array}{l}\text { East Siberian Platform, Irkutsk Amphitheatre, } \\
\text { Russia }\end{array}$ & $\mathrm{i}, \mathrm{ch}$ & & & [89] \\
\hline 37 & Upper Neo-proterozoic $^{2}$ & Salt Range Formation & Salt Range, Pakistan & \multicolumn{3}{|c|}{ co, ch, i, ch-s, s } & [90] \\
\hline 38 & Upper Neo-proterozoic ${ }^{2}$ & Tyrsk, Oskobin Suite & $\begin{array}{c}\text { East Siberian Platform, Irkutsk Amphitheatre, } \\
\text { Russia }\end{array}$ & $\mathrm{t}$ & & & [91] \\
\hline
\end{tabular}

${ }^{1}$ The age is subject to discussion; may be older (Karpatian- $\left.[92-94]\right) ;{ }^{2}$ indicates formations deposited from seawater of SO4-rich chemical type $;{ }^{3}$ indicates formations deposited from seawater of Ca-rich chemical type. 
For this study, only those publications have been considered in which clay minerals were determined by the X-ray method. In the 1960s and 1970s, when XRD methods began to be widely used for mineralogical research, numerous papers were published, listing associations of clay minerals of evaporite deposits in different regions. However, in some works in the early 1960s, when terminology and modern methods for clay minerals determination were still being developed, the authors did not determine the separate mixed-layer phases and described them as "several varieties of expandable random mixed-layer clay minerals" [95], and such publications have been ignored. In some cases, we have omitted, in Table 1, "impurities of paragonite? and rectorite?", punctuated by a question mark [38], "possible traces of vermicullite in several samples", and septechlorite [83]. Several minerals were reported to occur only once-serpentine, talc-smectite and hydrobiotite-vermiculite.

One methodological problem is related to a long period of preparation of publications and to the terminology that differs in particular languages. In order to make the results comparable, we have unified the names of clay minerals used by various authors. The names of clay minerals from the articles written in Ukrainian and Russian are changed to those accepted in English-language geological literature: hydro-mica and montmorillonite are changed to illite and smectite, respectively. In articles written in English and German, muscovite in the papers published around $1960[55,58,59,68]$ and mica [48] are changed to illite. We have reduced the accuracy of determination of clay minerals, which are defined as mineral species in some publications, to the group rank: clinochlorite [86] is changed to chlorite, and leucophillite (magnesium illite [80]) to illite.

For the Lower Permian and Devonian evaporite formations of the Dnipro-Donets Depression, Ukraine [65], we used only clay mineral association of "primary sedimentary type" rock salt, as those are bearing information on the seawater chemistry.

When comparing clay mineral association, a simple list of all the minerals occurring in evaporite formations is not very informative, since it does not allow us to distinguish between a mineral that is reported in every study concerning a certain evaporite formation and the mineral that is described only once. To reduce the impact of minerals that occur rarely, we calculated the relative occurrence of minerals for formations, concentration stages, and seawater chemical types. To find the relative occurrence of a mineral within a formation, we divided the number of papers that mention this mineral by the number of papers concerning a formation. The relative occurrence of a mineral within the concentration stage is the mean of the relative occurrence of all the formations of this stage. Thus, if the relative occurrence of illite at the potassium salt precipitation stage is $100 \%$, it means that illite was described in every paper concerning the stage. The same way we obtained the relative occurrence of a mineral for seawater type, and these data were used to compare the composition of clay mineral association.

In our calculations, we cannot consider the quantitative content of the mineral. Basic mineral and the admixture are considered in the same way in calculations, which to a certain degree obscures the results. Usually, authors do not give the contents of particular clay minerals. Table 1 shows the associations in the order given in particular publications, from more common to those occurring as an admixture. In our calculations, this order of minerals (from a greater to smaller concentration) disappears, and thus the basic mineral and the admixture are considered in the same way in calculations; thus, the results are obscured. For example, smectite or chlorite-smectite are reported to be quite common at the halite stage or potash stage (cf. Figure 5), but our experience indicates that the content of those minerals is quite small as they occur in the form of admixture.

Clay minerals are sensitive to changes in the brine concentration. In this study, clay mineral association were compared separately for different lithological types of rocks: gypsum-anhydrite or carbonate-gypsum-anhydrite facies, rock salt facies and potassium salts facies, i.e. we consider them by stages of $\mathrm{K}^{+}$concentration. According to [96], the potassium concentration ranges are, in $\mathrm{g} / \mathrm{L}$, 1.5-3.9 for the sulfate-carbonate concentration stage, 3.9-26.1 for the halite stage and more than 26.1 for the potassium salts stage. 
The evaporite formations that we generalized are unevenly distributed over the Phanerozoic periods. This is caused by the uneven age distribution of evaporite deposits. The number of evaporite formations for $\mathrm{SO}_{4}$-rich and Ca-rich seawater types is also different. Nevertheless, in our opinion, the evaporite formations considered are representative enough for justifying the dependence of clay minerals on the stage of brine concentration and on the seawater chemical type during Phanerozoic times.

\section{Results}

\subsection{Associations of Clay Minerals of Phanerozoic Evaporites at Different Stages of Brine Concentration}

All considered publications provide descriptions of one to eight clay minerals in a water-insoluble residue of evaporite deposits. The associations contain mostly two or three minerals; for the $\mathrm{SO}_{4}$-rich seawater chemical type, such associations make up 52.7-55.5\%, for the Ca-rich type-50-83.3\%. For the $\mathrm{SO}_{4}$-rich seawater chemical type, associations of 5-8 minerals occur at all stages of brine concentration, and for the Ca-rich type, there are usually not more than four minerals in association (once 5 and once 6 minerals). There are two histograms of the quantitative distribution of minerals in associations that contain two maxima each (Figure 2).
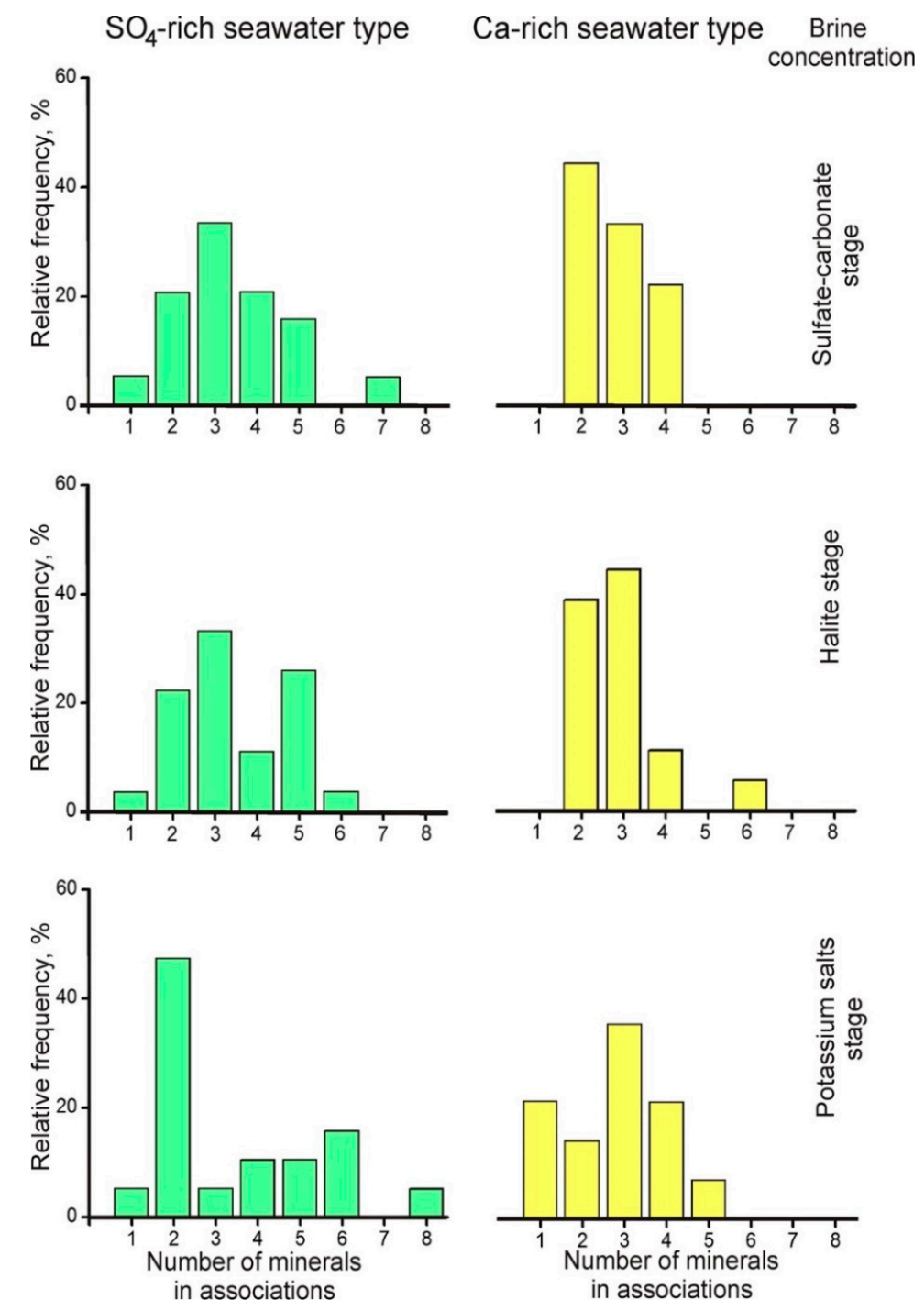

Figure 2. Quantitative distribution of clay mineral association of Phanerozoic evaporite formations deposited from seawater of $\mathrm{SO}_{4}$-rich and Ca-rich chemical types. 
Associations of clay minerals of evaporites are formed mostly under the impact of basin brine-some clay minerals (kaolinite, smectite, corrensite, and disordered mixed-layer minerals) are unstable in the hypersaline environment and transform in order to adapt to new conditions. This also reduces their content-from the basic minerals, they move into the category of admixture. This eventually leads to their disappearance and decrease in the number of minerals in the association.

The typical change in the associations of clay minerals at different stages of brine concentration can be illustrated by the Badenian (middle Miocene) evaporite deposits of the Ukrainian Carpathian Foredeep (for more details, see [97]). Here, smectite is predominant in the sulfate-carbonate stage deposits; there are smaller amounts of illite, chlorite and admixture of illite-smectite and chlorite-smectite. Consequently, five minerals [21] or three minerals [19] are reported there. At the halite stage, besides illite and chlorite, the Badenian deposits contain smectite, the content of illite-smectite and chlorite-smectite increases, and corrensite appears. Thus, six minerals [24] or five minerals [25] are found. Small amounts of smectite occur at the beginning of the halite stage. Then, smectite, mixed-layer minerals and corrensite disappear with increasing concentration, and only illite and chlorite remain in the deposits at the end of the halite stage [25]. At the potassium salts stage, clay minerals are represented by illite and chlorite [23,97-99]. The decrease in the number of clay minerals with increasing concentration of brines for the Miocene evaporite basin of the Carpathian Foredeep is obvious.

A clear decrease in the number of clay minerals along with the progressive brine concentration is noted in the Upper Permian Zechstein evaporites of West Germany [55]. Deposits of the sulphate-carbonate stage of concentration contain not only illite and chlorite but also smectite, mixed-layer minerals and corrensite (7 minerals in total). At the halite stage, corrensite is the only swelling mineral left (only 3 minerals in total), and at the potassium salts stage, only illite and chlorite are present.

For some evaporite formations, observations coincide with theoretical ideas about the course of transformation processes under the impact of progressive brine concentration. However, in the material generalized for 38 Phanerozoic formations, we did not see a decrease in the number of clay minerals along with increasing salinity. Dependence on concentration became noticeable when we used the relative occurrence of individual minerals instead of a simple list of minerals (Table 2).

Table 2. Relative occurrence of most common clay minerals in Phanerozoic marine evaporite formations at different stages of brine concentration.

\begin{tabular}{|c|c|c|c|}
\hline \multirow{2}{*}{ Seawater Chemical Type } & \multicolumn{3}{|c|}{ Brine Concentration Stages } \\
\hline & Sulfate-Carbonate & Halite & Potassium Salts \\
\hline \multicolumn{4}{|c|}{$\mathrm{SO}_{4}$-rich seawater chemical type ( 23 formations) } \\
\hline The number of analyzed formations for each concentration stage & 16 & 12 & 7 \\
\hline The number of described clay minerals & 12 & 11 & 11 \\
\hline Illite relative occurrence, $\%$ & 78.8 & 83.3 & 100 \\
\hline Chlorite relative occurrence, $\%$ & 70.3 & 83.3 & 80.0 \\
\hline Smectite relative occurrence, $\%$ & 42.8 & 30.3 & 8.6 \\
\hline $\begin{array}{l}\text { Total relative occurrence of swelling minerals (smectite, } \\
\text { ch-s—chlorite-smectite, ch-v—chlorite-vermiculite, co-corrensite, } \\
\text { i-s—illite-smectite), divided by minerals number, in \% }\end{array}$ & 28.5 & 32.8 & 19.1 \\
\hline \multicolumn{4}{|c|}{ Ca-rich seawater chemical type (15 formations) } \\
\hline The number of analyzed formations for each concentration stage & 6 & 10 & 5 \\
\hline The number of described clay minerals & 7 & 8 & 9 \\
\hline Illite relative occurrence, $\%$ & 100 & 100 & 98 \\
\hline Chlorite relative occurrence, $\%$ & 67 & 100 & 94 \\
\hline Smectite relative occurrence, $\%$ & 16.7 & 7.5 & 24 \\
\hline $\begin{array}{l}\text { Total relative occurrence of swelling minerals (smectite, } \\
\text { ch-s—chlorite-smectite, ch-v—chlorite-vermiculite, co—corrensite } \\
\text { i-s—illite-smectite), divided by minerals number, in \% }\end{array}$ & 18.8 & 10.8 & 19.5 \\
\hline
\end{tabular}


In particular, as the concentration increases, for the $\mathrm{SO}_{4}$-rich seawater type, the relative occurrence of illite rises, and decreases for smectite and mixed-layer minerals. In turn for the Ca-rich type, the relative occurrence of smectite and mixed-layer minerals first falls from the sulphate-carbonate to the halite stage, and then increases at the potassium salts stage. For seawater of both types, the relative occurrence of chlorite slightly decreases at the stage of potassium salts precipitation (Figure 3).
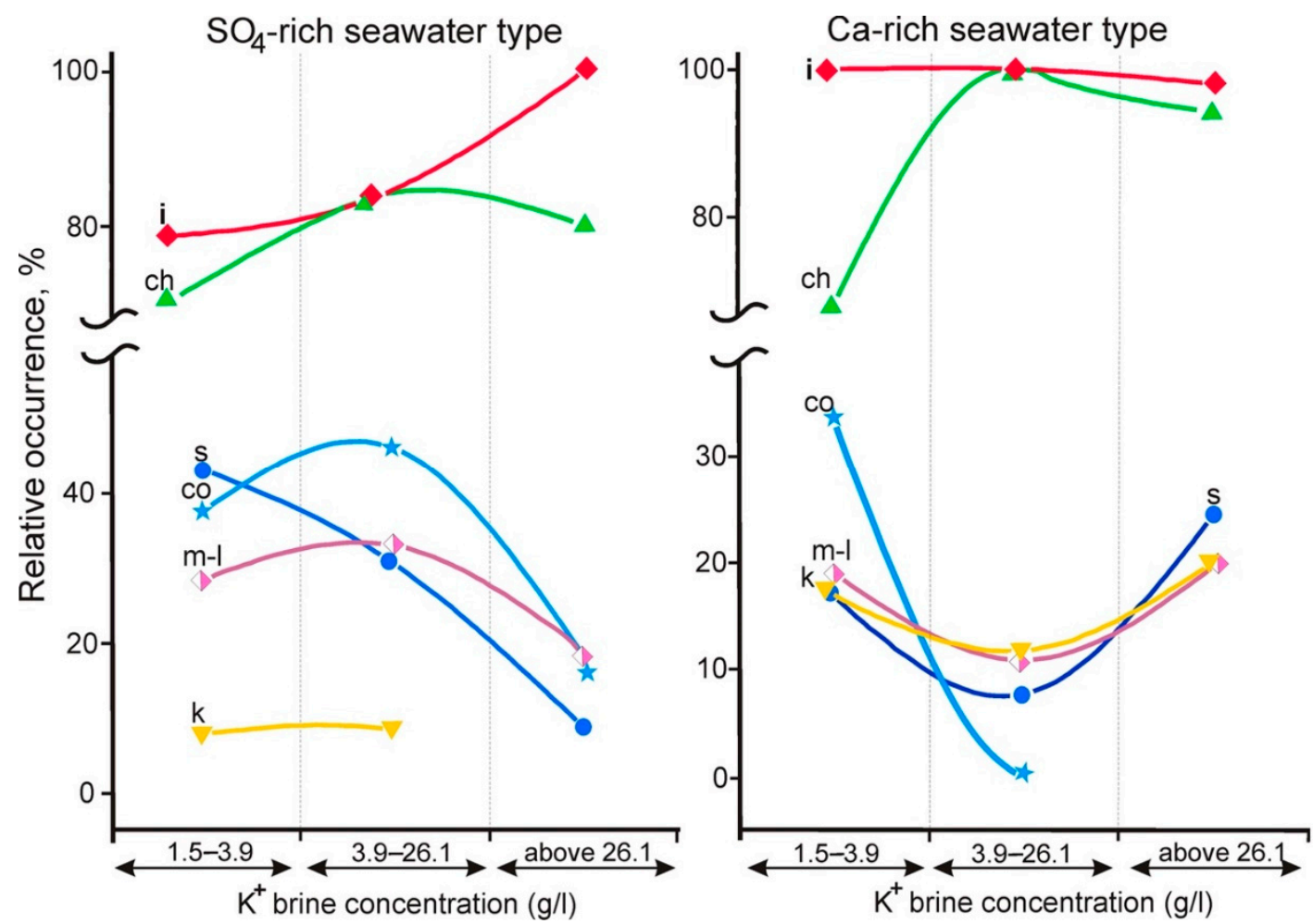

Figure 3. Relative occurrence of clay minerals that take part in transformations at different stages of brine concentration (concentration ranges for different stages after [96]); ch—chlorite, co-corrensite, i-illite, k-kaolinite, m-l-mixed-layer minerals, s—smectite.

In most of the 74 publications analyzed, the associations of clay minerals of one concentration stage are described, and only in 19 publications the authors provide data on association for two or three concentration stages for the same formation. We can expect that local factors equally affect the deposition in all stages and do not distort the results, so we considered these results separately (Table 3). Of those formations discussed in Table 3, 15 publications give information about the clay minerals of evaporites that formed during the periods of $\mathrm{SO}_{4}$-rich seawater type, and 4-Ca-rich type.

In formations, in which more than one concentration stage is described in one paper, with the progressive increase of brine salinity, the number of clay minerals in the associations changes as follows: decreases in nine cases (all of them belong to the $\mathrm{SO}_{4}$-rich seawater chemical type); remains the same in six cases (four of them belong to the Ca-rich seawater type); and increases in four cases (three of which belong to the $\mathrm{SO}_{4}$-rich type). For the $\mathrm{SO}_{4}$-rich type of seawater, with increasing concentration, the theoretically expected decrease in the number of clay minerals in the associations is mainly observed, and for the Ca-rich seawater type, the unchanged number of minerals is more often characteristic.

The expected direction of transformations is contradicted by the composition of the clay mineral association of potassium-bearing rocks-evaporites of the highest stage of brine concentration, which contain mostly three-four minerals. In some cases, they contain a greater number-five-eight, including two-three mixed-layer minerals and even smectite. It is explained by the impact of coeval intense volcanism. Some evaporite basins (Salado Formation and Zechstein-both Upper Permian; Caspian Basin, Inder Dome; Dnipro-Donets Depression-Lower Permian; Maha Sarakham 
Formation-Cretaceous-Paleogene; Pripyat Basin, Starobinsk deposit of potassium salts-Upper Devonian; Prairie Formation-Middle Devonian) received a significant amount of pyroclastic material at this stage. The intermediate products of its transformation (in the form of swelling minerals) are present in the potassium-bearing deposits of these formations.

Table 3. Changes in clay minerals at different stages of brine concentration. Formation number as in Table 1; ch—chlorite, ch-s—chlorite-smectite, co-corrensite, i-illite, i-s—illite-smectite, k-kaolinite, $\mathrm{s}$ - smectite, $\mathrm{sp}$ - sepiolite, $\mathrm{t}$-talc, $\mathrm{t}$-s—-talc-smectite.

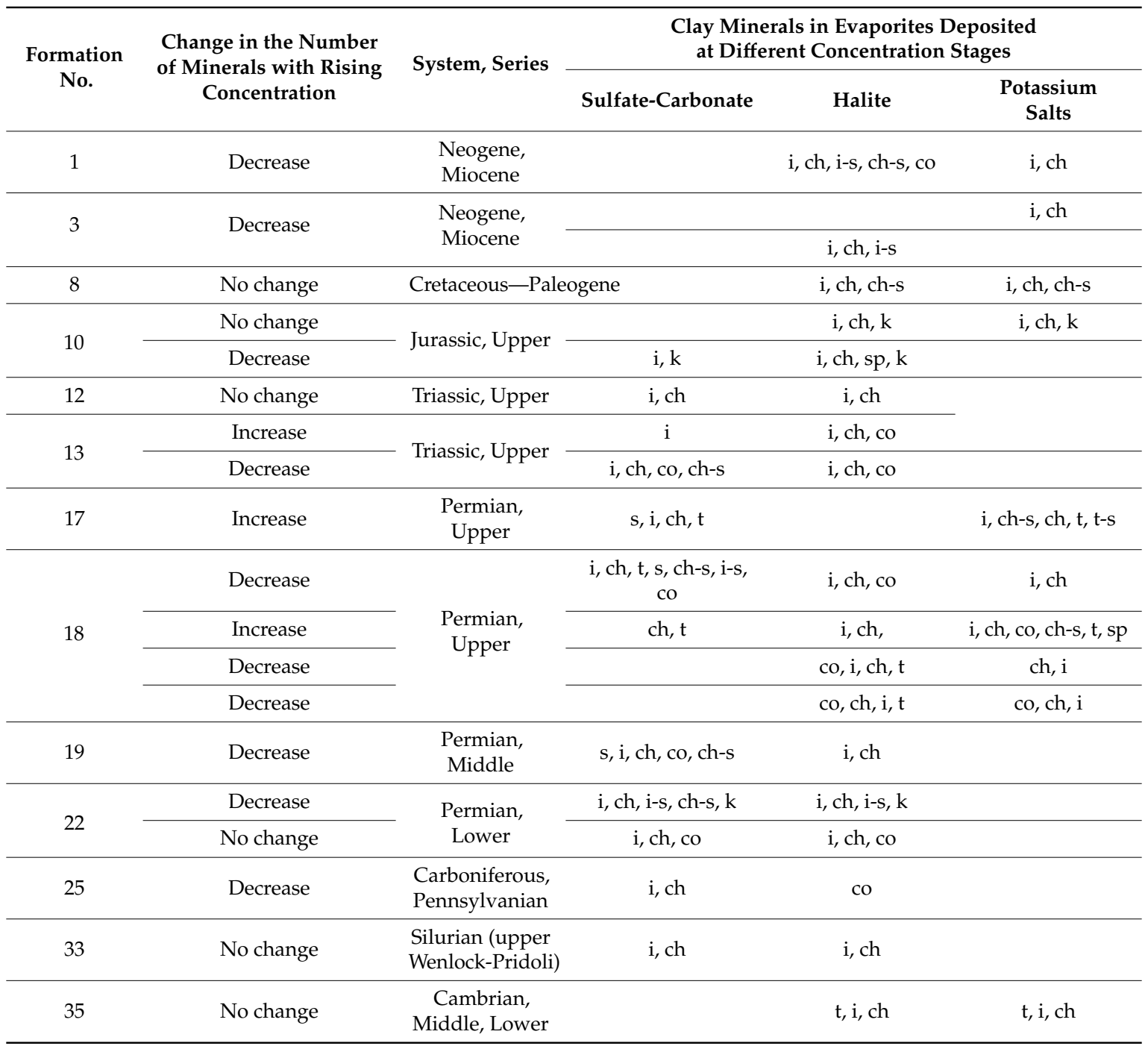

\subsection{Dependence of Clay Mineral Association of Phanerozoic Evaporite Formations on the Seawater Chemical Type}

Evaporites that formed from the $\mathrm{SO}_{4}$-rich or Ca-rich seawater differ in the clay minerals (Figure 4). For the $\mathrm{SO}_{4}$-rich seawater type, the total number of minerals in the deposits of all the stages of concentration is greater and is 12-11-11 for three stages, versus 7-8-9, for the Ca-rich type (Table 2). It was noted that the $\mathrm{SO}_{4}$-rich seawater type shows a greater number of minerals in associations (Figure 2) and a greater variety of clay minerals. Common minerals for both types are illite and chlorite. Smectite and mixed-layer minerals—illite-smectite, chlorite-smectite, chlorite-vermiculite-although characteristic of both types, are more common in $\mathrm{SO}_{4}$-rich seawater. However, there are some clay minerals associated mainly with evaporites, formed during the periods of $\mathrm{SO}_{4}$-rich seawater-these are magnesium-rich clay minerals: Mg-corrensite, palygorskite, sepiolite and talc (Figure 5). 

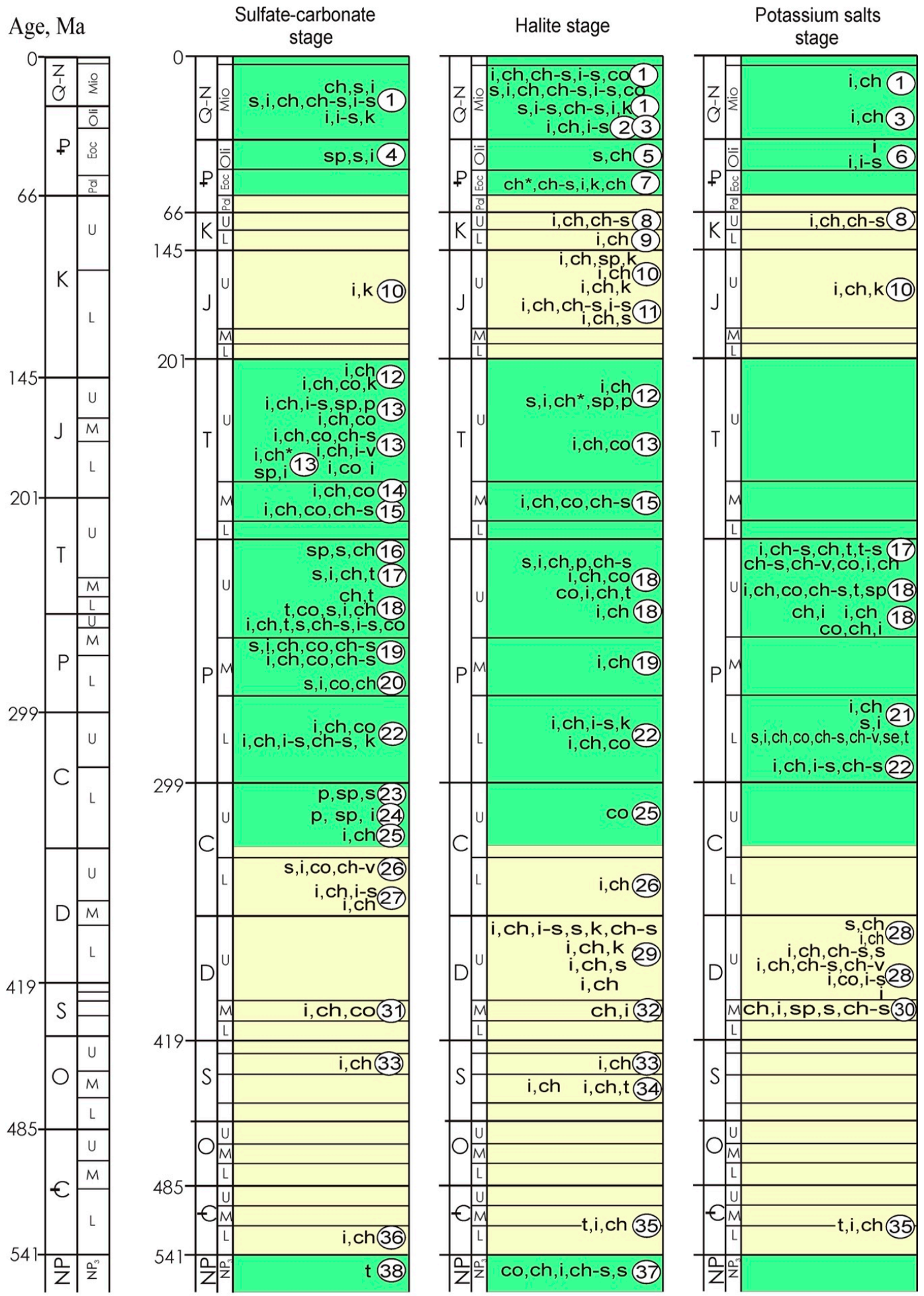

- periods of $\mathrm{SO}_{4}$-rich seawater

$\square$ - periods of Ca-rich seawater

Figure 4. The compositions of clay mineral association of Phanerozoic and Upper Proterozoic evaporite formations deposited from seawater of $\mathrm{SO}_{4}$-rich and Ca-rich chemical types. Minerals: ch—chlorite, ch*-swelling chlorite, ch-s—chlorite-smectite, ch-v—chlorite-vermiculite, co-corrensite, $\mathrm{hb}-\mathrm{v}$-hydrobiotite-vermiculite, i-illite, i-s-illite-smectite, $\mathrm{k}$-kaolinite, $\mathrm{p}$-palygorskite, s-smectite, se-serpentine, $\mathrm{sp}$-sepiolite, $\mathrm{t}$ - talc, $\mathrm{t}$-s—-talc-smectite. 


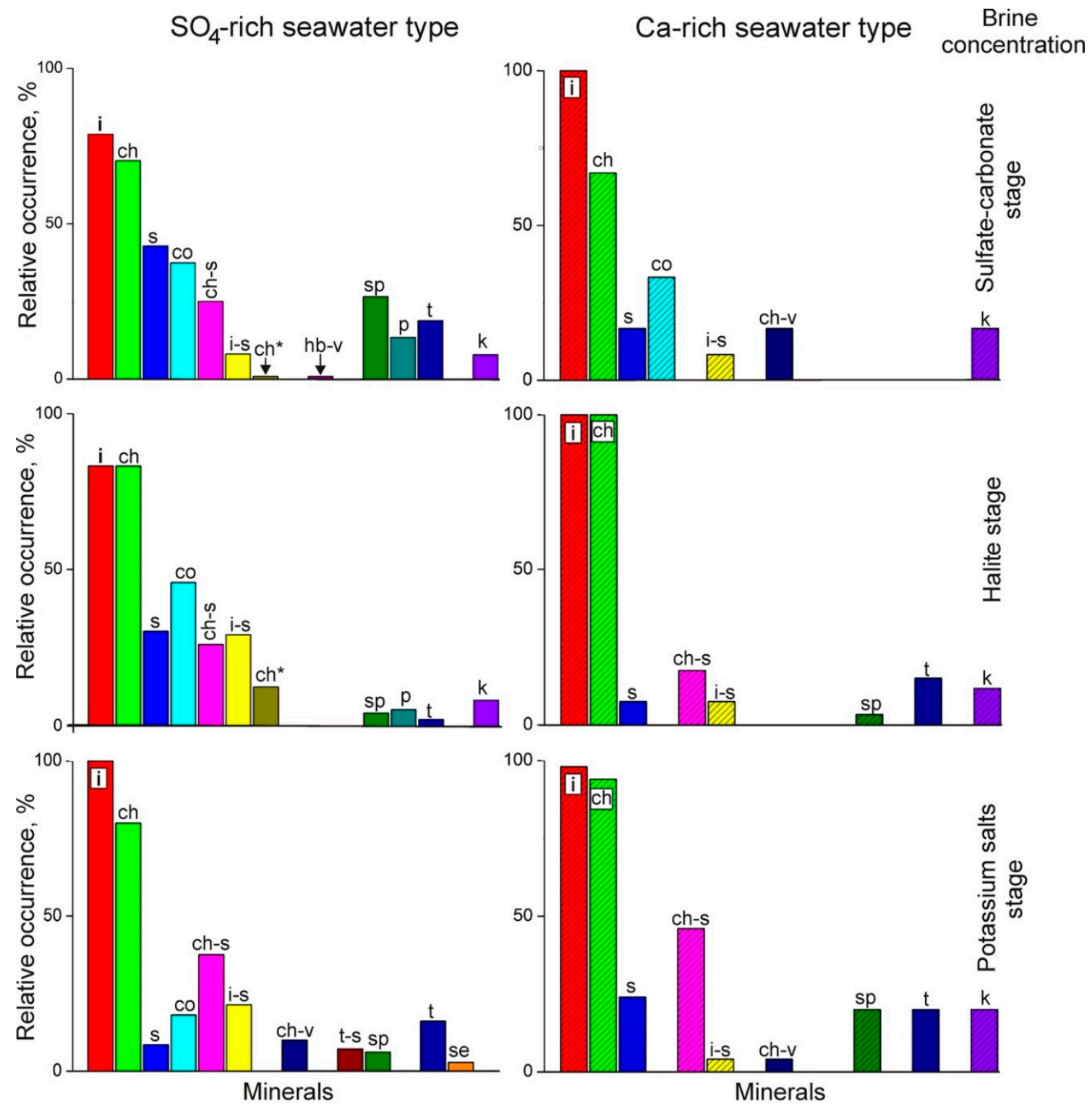

Figure 5. Relative occurrence of clay minerals of Phanerozoic evaporite formations deposited from seawater of $\mathrm{SO}_{4}$-rich and Ca-rich chemical types. Minerals: illite (i), chlorite (ch), smectite (s), corrensite (co), chlorite-smectite (ch-s), illite-smectite (i-s), swelling chlorite ( $\left.\mathrm{ch}^{*}\right)$,chlorite-vermiculite (ch-v), hydrobiotite-vermiculite $(\mathrm{hb}-\mathrm{v})$, talc-smectite $(\mathrm{t}-\mathrm{s})$, sepiolite $(\mathrm{sp})$, palygorskite $(\mathrm{p})$, talc $(\mathrm{t})$, serpentine (se), kaolinite (k).

Magnesium-rich minerals in the Phanerozoic evaporites are rather unevenly distributed-they occur in 24 evaporite formations (out of 38). In the evaporites formed from $\mathrm{SO}_{4}$-rich seawater, several magnesium-rich minerals are described in each formation, namely Permian ( 7 formations), Triassic (4 formations), Pennsylvanian (3 formations), Upper Neoproterozoic ( 2 formations), as well as Neogene and Paleogene (one formation in each system). In the Jurassic, Mississippian, Silurian and Cambrian deposits, there is one formation in each system (and two formations in the Devonian), each containing one magnesium-rich mineral-all these formations were formed during the time intervals characterized by Ca-rich seawater (Table 4, Figure 6). 
Table 4. Occurrence of magnesium-rich clay minerals of Phanerozoic evaporite deposits formed from concentrated $\mathrm{SO}_{4}$-rich and Ca-rich chemical types of seawater. In brackets the number of findings in deposits formed at different stages of concentration (sulfate-carbonate-halite-potassium salts) is given.

\begin{tabular}{ccccc}
\hline $\begin{array}{c}\text { Mg-Rich Clay } \\
\text { Mineral }\end{array}$ & \multicolumn{2}{c}{ SO $_{4}$-Rich Seawater Chemical Type } & \multicolumn{2}{c}{ Ca-rich Seawater Chemical Type } \\
\hline $\begin{array}{c}\text { Mineral, Total } \\
\text { Number of Findings }\end{array}$ & $\begin{array}{c}\text { Number of } \\
\text { Mineral } \\
\text { Findings }\end{array}$ & $\begin{array}{c}\text { System; Formation } \\
\text { Number } \\
\text { as in Table } 1\end{array}$ & $\begin{array}{c}\text { Number of } \\
\text { Mineral } \\
\text { Findings }\end{array}$ & $\begin{array}{c}\text { System; Formation } \\
\text { Number as in } \\
\text { Table 1 }\end{array}$ \\
\hline Corrensite, 29 & $27(13-10-4)$ & $\begin{array}{c}\text { Neogene 1; Triassic 12, 13, } \\
14,15 ; \text { Permian 17, 18, 19, 20, } \\
\text { 21, 22; Pennsylvanian 25; } \\
\text { Upper Neoproterozoic 37 }\end{array}$ & $2(2-0-0)$ & $\begin{array}{c}\text { Mississippian 26; } \\
\text { Devonian 31; }\end{array}$ \\
\hline Sepiolite, 10 & $8(6-1-1)$ & $\begin{array}{c}\text { Paleogene 4; Triassic 12, 13; } \\
\text { Permian 16, 18; } \\
\text { Pennsylvanian 23, 24 }\end{array}$ & $2(0-1-1)$ & Jurassic 10; Devonian 30 \\
\hline Palygorskite, 5 & $5(3-2-0)$ & $\begin{array}{c}\text { Triassic 12, 13; Permian 18; } \\
\text { Pennsylvanian 23, 24 }\end{array}$ & 0 & Silurian 34; Cambrian 35 \\
\hline Talc, 13 & $10(5-2-3)$ & $\begin{array}{c}\text { Permian 17, 18, 21; Upper } \\
\text { Neoproterozoic 38 }\end{array}$ & $3(0-2-1)$ & \\
\hline
\end{tabular}

Sepiolite is described seven times in association with smectite and/or with mixed-layer minerals (with corrensite-only once), three times-without them. Palygorskite is described four times in association with sepiolite, once occuring without it. Talc is described six times in association with corrensite, smectite, and mixed-layer minerals, and only once with sepiolite. Serpentine and talc-smectite are described once in Permian evaporite deposits; their presence further emphasizes the elevated magnesium content in Permian basin brines.

Thus, when comparing clay mineral associations of evaporites of different ages, it is revealed that the characteristic features of the evaporites that formed during the periods of $\mathrm{SO}_{4}$-rich seawater dominance are both a greater number of minerals in associations that more often contain smectite and mixed-layer minerals and the appearance of additional clay minerals-corrensite, palygorskite, sepiolite and talc.

\section{Discussion}

\subsection{Dependence of Clay Minerals of Phanerozoic Evaporites on the Stages of Brine Concentration}

Clay minerals are indicators of the physical and chemical conditions of the environment, to which they react sensitively by transformations. In particular, increasing salinity accelerates the ordering of their structure.

The data used in this study often do not fit the theoretical scheme of clay minerals transformations. In our opinion, this is primarily because of the fact that the precipitation of evaporite deposits in addition to general global factors (seawater chemical type, regularities of the process of clay minerals transformation) is also influenced by other, local factors.

Some clay minerals become unstable and easily transformed in the evaporite basin under the action of highly mineralized brines. Clay minerals like smectite, mixed-layer minerals and kaolinite that are unstable in a hypersaline environment are transformed into stable ones (illite, chlorite) [1,2,4,100-102]. This is due to the capture of cations in the interlayer spaces of the swelling minerals and the ordering of their structure. With progressive brine concentration in the evaporite basin, the transformation processes become more intense. In this case, the amount of clay minerals in the association decreases and only illite and chlorite remain in the deposits of the potassium salt precipitation stage $[32,97,98]$.

Smectite, allogenic dioctahedral, or authigenic trioctahedral (formed from volcanic glass in the evaporite basin) is transformed through mixed-layer minerals of illite-smectite and chlorite-smectite composition (disordered; or ordered—corrensite) to illite and chlorite $[1,2,100]$. Kaolinite is unstable in 
the evaporite basin, and disappears in the deposits of potassium salt precipitation stage. It may occur in the deposits precipitated at the sulfate-carbonate stage and the beginning of the halite stage [10,48], sometimes in the marginal part of the basin, at the periphery [42], which, in such cases, can be explained by an insufficient concentration of brines to transform this mineral.

The decrease in the number of clay minerals with increasing concentration, which is clearly noticeable in the Neogene evaporite deposits of the Carpathian Foredeep and the Upper Permian evaporites of West Germany, is caused by aggradation transformation processes. In both formations, the deposits of all stages of concentration contain illite and chlorite; at the initial, sulphate-carbonate stage, smectite and mixed-layer minerals are also present. In the Zechstein deposits, in addition to these minerals, there are also corrensite and kaolinite, that is, there are minerals that will transform into illite and chlorite, which will reduce the number of minerals. At the halite stage, the brine concentration range is quite large, which leads to changes in clay mineral association. At the beginning of the stage, the transformations cause a decrease in the relative occurrence of smectite and an increase in corrensite and disordered mixed-layer minerals, and then their complete disappearance in deposits by the end of the stage. This is clearly seen in the Miocene of the Carpathian Foredeep. The halite stage deposits show an increase in the amount of clay minerals to five-six, and corrensite appears.

The Phanerozoic data summarized in Table 2 and Figure 5 indicate that the $\mathrm{SO}_{4}$-rich seawater type shows an increase in total frequency of occurrence of swelling minerals from $28.5 \%$ (sulphate-carbonate stage) to $32.8 \%$ (halite stage). At the end of the halite stage, the concentration of brines becomes high enough with the completion of transformation processes and the clay minerals association can contain only illite and chlorite. The presence of magnesite at the end of the halite stage [25], which is characteristic of potassium deposits [103], also confirms brine concentration close to that of the potassium salt precipitation stage. Apparently, the Zechstein rock salt, in which corrensite is the only swelling mineral, precipitated near the end of the halite stage. In the deposits of potassium salt precipitation stage, only illite and chlorite remained in both formations.

Although illite and chlorite are considered stable minerals of higher stages of concentration, the relative occurrence of chlorite in the deposits of potassium salt precipitation stage decreases by 3-6\% compared with the halite stage; also, the relative occurrence of illite for the Ca-rich seawater type decreases by $2 \%$ (Table 2). This needs to be clarified. It is possible that chlorite becomes less stable at high stages of concentration, although we have not found evidence of such behaviour of this mineral in the literature.

When clay minerals are simply listed without taking into account how often each mineral occurs, the pattern is not obvious. The number of minerals does not change with increasing concentration and amounts to 12-11-11 minerals for $\mathrm{SO}_{4}$-rich seawater and to 7-8-9 minerals for the Ca-rich seawater type (Table 2, Figure 5). The relative occurrence of minerals is much more informative. When using it for the same data, it becomes clear that, with increasing concentration, transformations occur in the expected direction: the percentage of illite and chlorite increases, and that of smectite and mixed-layer minerals decreases. This is especially noticeable for clay minerals of evaporite deposits, which formed from $\mathrm{SO}_{4}$-rich seawater. The input of volcanic material into the evaporite basin changes this pattern by increasing the number of unstable minerals. A significant amount of pyroclastic material was supplied to some evaporite basins at the potassium salt precipitation stage. Despite the high brine concentration, it was not fully transformed. These evaporite formations are characterized by a number of intermediate transformation products in the evaporites of the potassium salts stage of both the $\mathrm{SO}_{4}$-rich (five formations, mainly Permian) and the Ca-rich (three formations, mainly Devonian) seawater. Unexpectedly, in potassium-bearing deposits that formed from each type of seawater, there are only two formations in each seawater type, which do not contain swelling minerals (out of seven formations described for $\mathrm{SO}_{4}$-rich, and five for Ca-rich seawater type). Coeval volcanism at the stage of potassium salt precipitation was manifested quite often, i.e. in two-thirds of evaporite formations.

Swelling minerals in potassium-bearing deposits are unevenly distributed. Thus, from potassium salts of the Starobinsk deposit (Pripyat depression, Devonian), where the presence of volcanic 
material was detected at different levels of potassium-bearing and oversalt deposits [104], four publications [72-74,76] report the occurrence of only illite and chlorite in the pelitic fraction, and the other four [75,77-79] the presence of smectite and/or mixed-layer minerals of chlorite-smectite and chlorite-vermiculite composition. These swelling minerals are the products of incomplete transformation of tuffogenic material that entered the evaporite basin as a result of intense volcanism, synchronous with salt deposition. It must be mentioned that in the potassium-bearing strata of this deposit, there are layers of green clays with a thickness of 1 to $10 \mathrm{~cm}$ and even up to $1 \mathrm{~m}$ [80], displaying a vitroclastic texture, in which the pyroclastic material is replaced completely by monomineral $(95 \%)$ leukophyllite (magnesium illite) [79], without any admixture of smectite or mixed-layer minerals.

Volcanic material entered the evaporite basins also at the sulfate-carbonate and halite stages of concentration, but it is not always possible to unambiguously identify traces of its transformation in the clay mineral association. In the Carpathian Foredeep, the presence of a set of swelling minerals (smectite, corrensite, mixed-layer minerals) is due to Badenian volcanism, coeval with halite precipitation [25,97]. The influence of repeated simultaneous volcanic activity on the evaporite basins at the halite stage of brine concentration is evidenced indirectly by the bimodal distribution of clay minerals in the associations (Figure 2). They may indicate the imposition of two processes-in our case it can be an increase in the concentration of brines and the input of pyroclastic material into the evaporite basin. The increase in the relative occurrence of associations containing five clay minerals, which creates another maximum, is characteristic only of rock salt formed from the $\mathrm{SO}_{4}$-rich seawater type.

In 19 cases, the clay mineral association of deposits of more than one stage of brine concentration for one formation are described (Table 3). When analyzing these data, we have noticed that smectite and mixed-layer minerals occur in those nine formations where the amount of clay minerals decreases along with progressive brine concentration. They can be transformed into illite and chlorite, which will result in a decrease in the number of minerals. In those six formations (four of which are Ca-rich), where the number of minerals remains unchanged, there are no swelling minerals that could be transformed, and consequently, there is a decrease in the number of minerals. So, the question arises, why smectite and mixed-layer minerals are absent in these four evaporite deposits that formed from the Ca-rich seawater type? In all 15 Phanerozoic formations formed from the Ca-rich seawater type, the relative occurrence of swelling minerals is lower than in that of $\mathrm{SO}_{4}$-rich type (Table 2, Figure 5). We assume that the low relative occurrence of swelling minerals may indicate the absence of synchronous volcanism or its low activity. This conclusion does not coincide with the time distribution of volcanic activity during the Phanerozoic, the activity of which correlates with the periods of Ca-rich seawater $[3,105,106]$.

Thus, with increasing concentration, the number of minerals (in the deposits of the final halite stage and of the stage of potassium salt stage) decreases due to aggradation transformation processes, by converting swelling minerals into illite and chlorite. However, in some cases, we notice the increase in the number of clay minerals in the associations of potassium salts that was supposedly caused by intense volcanic activity synchronous with the evaporite deposition. Consequently, a significant amount of volcanic ash was brought into the evaporite basin, and if the transformation process was not completed, the products of incomplete transformation (smectite, mixed-layer minerals and corrensite) remained in the association of clay minerals of the halite stage or the potassium salt stage.

\subsection{Dependence of Clay mineral association of Phanerozoic Evaporite Deposits on the Seawater Chemical Type}

By comparing the data on the deposits of the respective stages of precipitation of 38 Phanerozoic evaporite formations, we found that the $\mathrm{SO}_{4}$-rich seawater type is characterized by both a larger number of clay minerals in associations and a greater variety of clay minerals. Evaporites that formed from the $\mathrm{SO}_{4}$-rich seawater type contain magnesium-rich clay minerals: $\mathrm{Mg}$-corrensite, palygorskite, sepiolite and talc $[107,108]$. They occur in 24 evaporite formations, 18 of which were deposited from the $\mathrm{SO}_{4}$-rich seawater type, and each contains several magnesium-rich minerals. At the stages of Ca-rich seawater, single magnesium-rich minerals are described from six formations (Figure 6). 
It is known that the tendency of slightly elevated magnesium content is inherent in almost all (except illite) clay minerals of evaporite deposits (e.g. [5,100]).

For magnesium-rich minerals (sepiolite, palygorskite, talc and corrensite), the path of direct precipitation from silica-, alumina-, and magnesium-rich solutions under certain physical and chemical conditions ( $\mathrm{pH}$, salinity, activity of silicon, aluminum, etc.) is the most acceptable process of formation and is confirmed by experimental work [5,109-112]. Silica and alumina entered the evaporite basin as a result of the destruction of unstable silicate or aluminosilicate minerals and volcanic ash, and the source of magnesium was concentrated $\mathrm{SO}_{4}$-rich seawater, which is characterized by elevated $\mathrm{Mg}$ content (Figure 6). Corrensite, in addition to precipitation from solutions, can be formed as an intermediate product of the conversion of smectite to chlorite [113]. The data considered by us show that there are sixteen cases in which corrensite occurs without chlorite-smectite, which may indicate its crystallization from aluminosilicate gel, and thirteen cases in which it is associated with chlorite-smectite, i.e. formed during the transformation of smectite into chlorite; thus, corrensite was formed in both of these ways. Pyroclastic material is required for the formation of magnesium-rich clay minerals: for corrensite - mainly of acidic rhyolite-trachyte, sometimes andesitic composition [114,115], for sepiolite and palygorskite-of alkaline basic composition $[34,110]$. This explains the fact that palygorskite is associated mainly with sepiolite, while corrensite (with one exception) does not occur with sepiolite. Thus, the formation of magnesium-rich minerals is usually associated with an elevated $\mathrm{Mg}$ content in seawater of $\mathrm{SO}_{4}$-rich chemical type and the input of pyroclastic material into the evaporite basin. Figure 6 shows that there are exceptions, as exemplified by the excursions of $\mathrm{Mg}$ in the Early Jurassic and Mississippian. The presence of magnesium clay minerals in some evaporite deposits was noted earlier $[4,100]$, but at that time, there was no information about variations in the seawater chemistry during the Phanerozoic, and thus the global cause of uneven age distribution of these minerals could not be revealed.

Only five formations deposited from seawater of $\mathrm{SO}_{4}$-rich type, all of Paleogene and Neogene age, contain no or very few magnesium-rich minerals. Two of them are Neogene formations of the Carpathian Foredeep - the Tereblya and Vorotyshcha suites (two finds of corrensite are reported from the third formation of this region-the Tyras suite). Their specific feature is a relatively low magnesium content. This is manifested not only by the absence of Mg-rich minerals, but also by the fact that chlorite has a Fe-Mg and Fe composition [23,97]. This may be due to a significant amount of terrigenous material brought into the Carpathian Foredeep evaporite basin. Single finds of magnesium-rich minerals—sepiolite (Upper Jurassic, Middle Devonian), corrensite (Mississippian, Middle Devonian) and talc (Upper Silurian, Lower and Middle Cambrian) — were also observed in clay mineral association of six evaporite formations deposited from the Ca-rich seawater type. This indicates the existence of some additional sources of magnesium for the formation of magnesium-rich clay minerals of these evaporite deposits.

The correlation of changes in clay mineral association with secular variations in seawater chemistry indicates that global processes in the history of the Earth have influenced the formation of associations of clay minerals of marine evaporite deposits. 


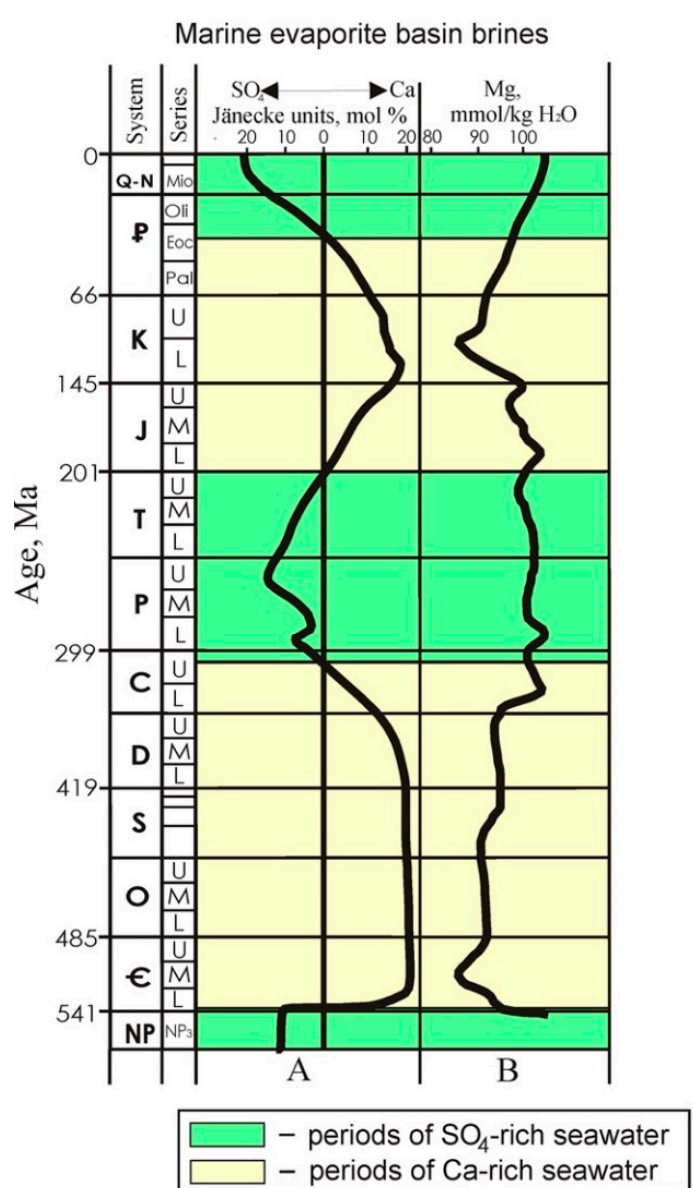

- sp, o - p, $\Delta$ - co, $\star$ - t, () - t-s, () - se

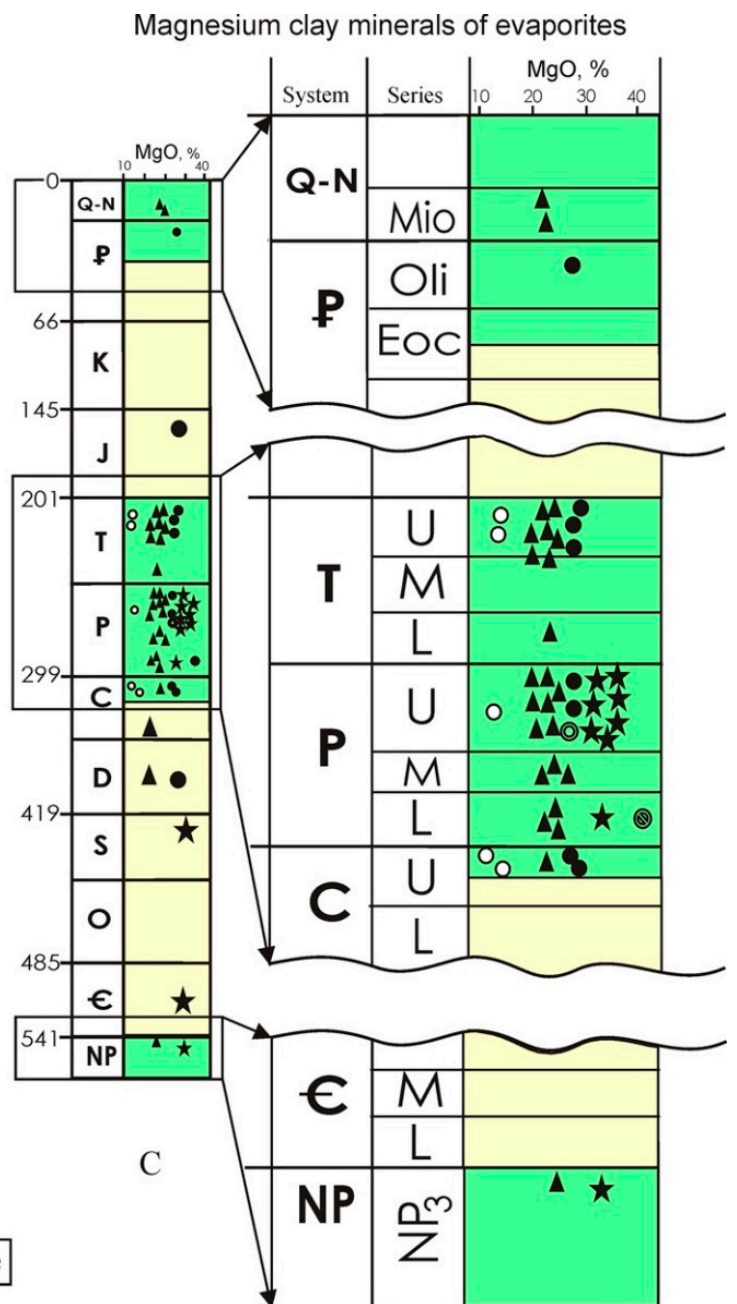

Figure 6. The correlation between secular variations in seawater chemistry (A, modified from [116]), $\mathrm{Mg}$ content in seawater (B, modified from [13]), and occurrence of Mg-rich clay minerals (C, modified from [108]); co-corrensite, $\mathrm{p}$-palygorskite, se—serpentine, $\mathrm{sp}$ - sepiolite, $\mathrm{t}$-talc, $\mathrm{t}$-s—-talc-smectite.

\section{Conclusions}

The synthesis of published data concerning 38 Phanerozoic marine evaporite formations indicates that the composition of clay mineral association of evaporites correlates with the change in the seawater chemical type. Associations of clay minerals, which formed at the periods of $\mathrm{SO}_{4}$-rich seawater type, are characterized by a larger number of minerals, among which smectite and mixed-layer minerals are frequent, and a common appearance of magnesium-rich clay minerals (corrensite, palygorskite, sepiolite and talc). In contrast, the clay mineral association of Ca-rich seawater show a smaller number of minerals, and magnesium-rich minerals are described only in isolated cases. The higher content of magnesium in the $\mathrm{SO}_{4}$-rich seawater type is the major factor in the formation of magnesium-rich silicates of evaporite deposits.

The composition of clay mineral association depends upon the concentration of brines in the salt basin; with its increase, unstable minerals are transformed, which theoretically leads to a decrease in the number of minerals in the associations. However, it was found that evaporite deposits of higher stages of brine concentration often still contain unstable clay minerals-products of incomplete transformation of pyroclastic material, a significant amount of which was introduced into the evaporite basin due to volcanic activity simultaneous with the evaporation process.

The study showed that the major factor determining the composition of clay mineral association of Phanerozoic evaporite formations was the seawater chemical type. 
Author Contributions: Conceptualization: Y.Y., S.H., T.P.; methodology: Y.Y., S.H., S.V.; investigation: Y.Y., S.H., S.V.; data curation: Y.Y., S.H.; formal analysis: Y.Y., S.H., T.P., S.V., F.M.; visualization: Y.Y., S.V., S.H.; writing—original draft preparation: Y.Y., S.H., S.V., F.M.; writing—review and editing: T.P., Y.Y., S.H., S.V.; All authors have read and agreed to the published version of the manuscript.

Funding: This research was supported by the National Academy of Sciences of Ukraine statutory funds (B-III-04-16), the Polish Geological Institute-National Research Institute statutory funds (Project No. 61.2805.1702.00.0) and the National Natural Science Foundation of China (Grant No.: 41561144009) and Basic Frontier Scientific Research Program of the Chinese Academy of Sciences (No.: ZDBS-LY-DQC021).

Acknowledgments: We are very grateful to V.M. Kovalevych for consultations and general guidance. We also thank K. Leszczyński for his helpful suggestions on an early manuscript, and to the journal referees for their comments.

Conflicts of Interest: The authors declare no conflict of interest.

\section{References}

1. Dunoyer de Segonzac, G. The transformation of clay minerals during diagenesis and low-grade metamorphism: A review. Sedimentology 1970, 15, 281-346. [CrossRef]

2. Frank-Kamenetskiy, V.A.; Kotov, N.V.; Goylo, E.L. Transformatsionnye Preobrazovaniya Sloistykh Silikatov; Nedra: Leningrad, USSR, 1983. (In Russian)

3. Kossovskaya, A.G.; Drits, V.A. Kristallokhimiya dioktaedricheskikh slyud, khloritov i korrensitov kak indikatorov geologicheskikh obstanovok. In Problemy Litologii i Geokhimii Osadochnykh Porod i Rud; Nauka: Moskva, USSR, 1975; pp. 60-69. (In Russian)

4. Sokolova, T.N. Autigennoe silikatnoe mineraloobrazovanie raznykh stadiy osolonennya. Tr. GIN 1982, 361 , 1-164. (In Russian)

5. Pozo, M.; Calvo, J.P. An Overview of Authigenic Magnesian Clays. Minerals 2018, 8, 520. [CrossRef]

6. Yanshin, A.L. Evolyutsiya Geologicheskikh Protsessov v Istorii Zemli; Nauka: Leningrad, USSR, 1988. (In Russian)

7. Garrels, R.M.; Mackenzie, F.T. Evolution of Sedimentary Rocks: A Geochemical Approach; Norton: New York, NY, USA, 1971.

8. Weaver, C.E. Potassium, illite, and the ocean. Geochim. Cosmochim. Acta 1967, 31, 281-296. [CrossRef]

9. Weaver, C.E. Origin and geologic implications of the palygorskite of the SE United States. Dev. Sedimentol. 1984, 37, 39-58.

10. Weaver, C.E. Clays, Muds, and Shales. Dev. Sedimentol. 1989, 44, 1-818.

11. Sandberg, P.A. An oscillating trend in Phanerozoic non-skeletal carbonate mineralogy. Nature 1983, 305, 19-22. [CrossRef]

12. Holland, H.D.; Lazar, B.; McCaffrey, M.A. Evolution of the atmosphere and oceans. Nature 1986, 320, $27-33$. [CrossRef]

13. Hardie, L.A. Secular variation in seawater chemistry: An explanation for the coupled secular variation in the mineralogies of marine limestones and potash evaporites over the past 600 m.y. Geology 1996, 24, 279-283. [CrossRef]

14. Kovalevych, V.M.; Peryt, T.M.; Petrichenko, O.I. Secular variation in seawater chemistry during the Phanerozoic as indicated by brine inclusions in halite. J. Geol. 1998, 106, 695-712. [CrossRef]

15. Lowenstein, T.K.; Timofeeff, M.N.; Brennan, S.T.; Hardie, L.A.; Demicco, R.V. Oscillations in Phanerozoic seawater chemistry: Evidence from fluid inclusions. Science 2001, 294, 1086-1088. [CrossRef] [PubMed]

16. Horita, J.; Zimmermann, H.; Holland, H.D. Chemical evolution of seawater during the Phanerozoic: Implications from the record of marine evaporites. Geochim. Cosmochim. Acta 2002, 66, 3733-3756. [CrossRef]

17. Holland, H.D. The geologic history of seawater. Treatise Geochem. 2003, 6, 583-625.

18. Bąbel, M.; Schreiber, B.C. Geochemistry of Evaporites and Evolution of Seawater. Treatise Geochem. 2014, 9, 483-560. [CrossRef]

19. Poberezhskiy, A.V. Fiziko-khimicheskie Usloviya Formirovaniya Badenskikh Sul'fatno-karbonatnykh Otlozheniy Predkarpat'ya (v Svyazi s Ikh Seronosnost'yu); Lviv, USSR, 1991. (In Russian)

20. Bobrovnik, D.P.; Karpenchuk, Y.R. K litologii i mineralogii verkhnetortonskikh otlozheniy tirasskoy svity vnutrenney zony Predkarpatskogo progiba. In Voprosy Litologii i Petrografii; Lviv University Publishing House: Lviv, USSR, 1969; Volume 1, pp. 46-56. (In Russian)

21. Yaremchuk, Y.V.; Poberezhs'kyy, A.V. Mineral'nyy sklad hlyn badens'kykh hipsiv Naddnistrov"ya. Mineral. Zb. 2009, 59, 116-127. (In Ukrainian) 
22. Bilonizhka, P.M.; Vinar, O.N.; Mel'nikov, V.S. O mineral'nom sostave glin solyanykh porod kaliynykh mestorozhdeniy Prikarpat'ya. In Voprosy Mineralogii Osadochnykh Obrazovaniy; Lviv University Publishing House: Lviv, USSR, 1966; Volume 7, pp. 147-158.

23. Oliyovych, O.; Yaremchuk, Y.; Hryniv, S. Hlyny halohennykh vidkladiv i kory zvitryuvannya Kalush-Holyns'koho rodovyshcha kaliynykh soley (miotsen, Peredkarpattya). Mineral. Zb. 2004, 54, 214-223. (In Ukrainian)

24. Yaremchuk, Y.V.; Halamay, A.R. Mineral'nyy sklad vodonerozchynnoho zalyshku badens'koyi kam"yanoyi soli Ukrayins'koho Peredkarpattya (dilyanka Hrynivka). Heol. Heokhim. Horyuch. Kop. 2009, 1, 79-90. (In Ukrainian)

25. Yaremchuk, Y.V.; Hryniv, S.P. Mineral'nyy sklad hlyn kam"yanoyi soli miotsenovykh evaporytiv Karpat·s'koho rehionu Ukrayiny. In Suchasni Problemy Litolohiyi i Mineraheniyi Osadovykh Baseyniv Ukrayiny ta Sumizhnykh Terytoriy; IHN Ukrayiny: Kyiv, Ukraine, 2008; pp. 209-215. (In Ukrainian)

26. Cebulak, S.; Janeczek, J.; Langer-Kuźniarowa, A.; Bzowska, G. Wskaźnikowe znaczenie minerałów ilastych skał zubrowych w badaniach mioceńskiej formacji solnej. In Mioceńskie Złoża Soli w Rejonie Przykarpackim; Akademia Górniczo-Hutnicza, Polskie Towarzystwo Geologiczne: Kraków, Poland, 2004. (In Polish)

27. Langier-Kuźniarowa, A.; Cebulak, S.; Starnawska, E.; Czapowski, G. Mineral composition of mixed clayely-salt deposits (zuber) from the Neogene (Upper Badenian) succession of the Polish Carpathian Foredeep. Mineral. Zb. 2002, 52, 101-105.

28. Środoń, J. Mixed-layer illite-smectite in low-temperature diagenesis: Data from the Miocene of the Carpatian Foredeep. Clay Miner. 1984, 19, 205-215. [CrossRef]

29. Bilonizhka, P.M. O mineral'nom sostave karbonatov i glin Solotvinskogo mestorozhdeniya kamennoy soli (Zakarpat'e). In Voprosy Geologii i Geokhimii Galogennykh Otlozheniy; Naukova dumka: Kiev, USSR, 1979; pp. 53-61. (In Russian)

30. Kityk, V.I.; Bokun, A.N.; Panov, G.M.; Slivko, E.P.; Shaydetskaya, V.S. Galogennye Formatsii Ukrainy: Zakarpatskiy Progib; Naukova dumka: Kiev, USSR, 1983. (In Russian)

31. Gabinet, P.M.; Slivko, E.P. Glinistye mineraly iz kamennoy soli rayona Svalyavy v Zakarpat'e. Mineral. Sb. 1984, 38, 56-62. (In Russian)

32. Ivanov, A.G.; Apollonov, V.N.; Borisenkov, V.I. Mineral'nye paragenezy galopelitov v otlozheniyakh kaliynykh soley. Dokl. AN SSSR 1980, 253, 469-472. (In Russian)

33. Rateev, M.A.; Osipova, A.I. Glinistye mineraly v otlozheniyakh aridnoy zony paleogena Fergany. Dokl. AN SSSR 1958, 123, 166-169. (In Russian)

34. Rateev, M.A. Zakonomernosti razmeshcheniya i genezis glinistykh mineralov v sovremennykh i drevnikh morskikh basseynakh. Tr. GIN 1964, 112, 1-273. (In Russian)

35. Gerasimova, V.V. Geologo-litologicheskaya kharakteristika i usloviya formirovaniya solenosnoy svity Severo-Zapadnoy Fergany. Tr. VNIIG 1960, 40, 169-215. (In Russian)

36. Millot, G. Relations entre la constitution et la genese des roches sedimentaires argileuses. Geol. Appl. Prosp. Min. 1949, 2, 1-352.

37. Yaremchuk, Y.; Vovnyuk, S.; Tarik, M. Hlynysti mineraly eotsenovoyi kam"yanoyi soli formatsiyi Bakhadar khel', Pakystan. Heol. Heokhim. Horyuch. Kop. 2020, 1, in press (In Ukrainian)

38. Suwanich, P. Clay-mineral assemblages from some levels of K-118 drill core of Maha Sarakham evaporites, northeastern Thailand. J. Asian Earth Sci. 1993, 8, 369-381. [CrossRef]

39. Popov, V.S.; Osichkina, R.G. Glinistye mineraly-Indikatory usloviy formirovaniya solyanykh tolshch (na primere galogennykh formatsiy Sredney Azii). In Khimiya i Tekhnologiya Mineral'nykh Udobreniy; Fan: Tashkent, USSR, 1971; pp. 155-176. (In Russian)

40. Khmelevskaya, E.V. Autigennye mineraly-primesi v verkhneyurskoy kamennoy soli Preddobrudzh'ya i Sredney Azii. Mineral. Sb. 1990, 44, 75-77. (In Russian)

41. Yaremchuk, Y.V. Zalezhnist' mineral'noho skladu pelitovoyi fraktsiyi vodonerozchynnoho zalyshku evaporytiv vid khimichnoho typu rozsoliv mors'kykh solerodnykh baseyniv. Heol. Heokhim. Horyuch. Kop. 2009, 3-4, 81-95. (In Ukrainian)

42. Kubler, B. La corrensite, indicateur possible de milieux de sedimentation et du degre de transformation d'un sediment. Bull. Cent. Rech. Pau SNPA 1973, 7, 543-556.

43. Lucas, J. La transformation des mineraux argileux dans la sedimentation. Etudes sur les argiles du Trias. Mém. Serv. Cart. Géol. Als. Lorr. 1962, 20,1-499. 
44. Schlenker, B. Petrographische Untersuchungen am Gipskeuper und Lettenkeuper von Stuttgart. Oberrh. Geol. Abh. 1971, 20, 69-102.

45. Lippman, F.; Savascin, M. Mineralogische Untersuchungen an Lösungsrückständen eines württembergischen Keupergipsvorkommens. Tschermak's Mineral. Petrogr. Mitt. 1969, 13, 165-190. [CrossRef]

46. Keeling, P.S. Sepiolite at a locality in the Keuper marl of the Midlands. Mineral. Mag. 1956, 31, 328-332. [CrossRef]

47. Honeyborne, D.B. The clay minerals in the Keuper Marl. Clay Miner. Bull. 1951, 1, 150-157. [CrossRef]

48. Fisher, M.J.; Jeans, C.V. Clay mineral stratigraphy in the Permo-Triassic red bed sequence of BNOC 72/10-1A, Western Approaches, and the South Devon coast. Clay Miner. 1982, 17, 79-89. [CrossRef]

49. Lucas, J.; Bronner, A.M. Evolution des argiles sedimentaires dans le basin triasique du Jura francais. Bull. Serv. Cart. Géol. Als. Lorr. 1961, 14, 137-149.

50. Becher, A. Eine Tonmineralfolge vom Beckenrend zum Beckeninneren im Buntsandstein Nordost Bayerns. Beitr. Mineral. Petrogr. 1965, 11, 586-613.

51. Bodine, M.W., Jr. Trioctahedral Clay Mineral Assemblages in Paleozoic Marine Evaporite Rocks. In Sixth International Symposium on Salt; Salt Institute: Alexandria, VA, USA, 1985; Volume 1, pp. 267-284.

52. Grim, R.E.; Droste, J.B.; Bradley, W.F. A mixed layer clay mineral associated with an evaporite. Clay Clay Miner. 1960, 8, 228-236. [CrossRef]

53. Langer-Kuźniarowa, A. Clay minerals of the Zechstein Oldest Rock Salt of northern Poland. In Tenth Conference on Clay Mineralogy and Petrology; Univerzita Karlova: Praha, Czechoslovakia, 1988; pp. 145-150.

54. Kühn, R. Zur Kenntnis des Könenits. N. Jb. Miner. Mh. 1951, 1, 1-16.

55. Füchtbauer, H.; Goldschmidt, H. Die Tonminerale der Zechsteinformation. Beitr. Mineral. Petrogr. 1959, 6, 320-345.

56. Pundeer, G.S. Mineralogy, genesis and diagenesis of a brecciated shaly clay from the Zechstein evaporite series of Germany. Contrib. Mineral. Petrol. 1969, 23, 65-85. [CrossRef]

57. Braitsch, O. Entstehung und Stoffbestand der Salzlagerstatten. In Mineralogie und Petrographie in Eizeldarstellungen; Springer: Berlin, Germany, 1962; Volume 3, pp. 1-232.

58. Braitsch, O. Salt Deposits, Their Origin and Composition; Springer: Berlin, Germany, 1971.

59. Braitsch, O. Mineralparagenesis und Petrologie der Stassfurtsalz in Reyerhaursen. Kali Steinsalz 1960, 1, 1-14.

60. Dreizler, I. Mineralogische untersuchungen in zwei Gipsvorkommen der Werraserie (Zechstein). Beitr. Mineral. Petrogr. 1962, 8, 323-338. [CrossRef]

61. Kossovskaya, A.G.; Sokolova, T.N. Grauvakki krasnotsvetnykh formatsiy Orenburgskogo Priural'ya. Tr. GIN 1972, 238, 280-284. (In Russian)

62. Kossovskaya, A.G.; Sokolova, T.N.; Drits, V.A.; Sakharov, B.A. Paragenezy i istoriya formirovaniya glinistykh mineralov v basseynakh nachal'noy stadii evaporitovoy sedimentatsii. In Problemy Litologii $i$ Geokhimii Osadochnykh Porod i Rud; Nauka: Moskva, USSR, 1975; pp. 279-296. (In Russian)

63. Borisenkov, V.I.; Apollonov, V.N.; Ivanov, A.G. Sostav galopelitov Verkhnekamskogo kaliynogo mestorozhdeniya kak geokhimicheskiy pokazatel' paleousloviy razvitiya solerodnogo basseyna. In Stroenie i Usloviya Formirovaniya Mestorozhdeniy Kaliynykh Soley; Nauka: Novosibirsk, USSR, 1981; pp. 110-118. (In Russian)

64. Shekhunova, S.; Yaremchuk, Y.; Shevchenko, O.; Kochubey, V. Osoblyvosti asotsiatsiyi hlynystykh mineraliv solenosnykh formatsiy Dniprovs'ko-Donets'koyi zapadyny. Mineral. Zb. 2010, 60, 92-122. (In Ukrainian)

65. Shekhunova, S.B. Osoblyvosti mineral'noho skladu fraktsiyi menshe $1 \mu \mathrm{m}$ vodonerozchynnoho zalyshku kam"yanoyi soli solenosnykh formatsiy Dniprovs'ko-Donets'koyi zapadyny. Heol. Zhurn. 2010, 1, 125-130. (In Ukrainian)

66. Shutov, V.D. Mineral'nye paragenezy grauvakkovykh kompleksov. Tr. GIN 1975, 278, 63-81. (In Russian)

67. Rateev, M.A. Mineralogiya i genezis palygorskitov i sepiolitov v morskikh otlozheniyakh karbona Russkoy platform. Litol. i Polezn. Iskop. 1963, 1, 58-72. (In Russian)

68. Nelson, S.W. Authigenic muscovite and chlorite in the Maccrady formation (abs.). Geol. Soc. Am. Bull. 1960, 71, 1935.

69. Peterson, M.N.A. Expandable chloritic clay minerals from Upper Mississippian carbonate rocks of the Cumberland Plateau in Tennessee. Am. Mineral. 1961, 46, 1245-1269.

70. Peterson, M.N.A. The mineralogy and petrology of Upper Mississippian carbonate rocks of the Cumberland Plateau in Tennessee. J. Geol. 1962, 70, 1-31. [CrossRef] 
71. Harrison, J.L.; Droste, J.B. Clay partings in gypsum deposits in southwestern Indiana. Clay Clay Miner. 1960, 7, 195-199. [CrossRef]

72. Yarzhemskiy, Y.Y. K petrografii Belorusskogo solyanogo mestorozhdeniya. Tr. VNIIG 1960, 40, $307-321$. (In Russian)

73. Shcherbina, V.N. O sootnosheniyakh karbonatno-glinistogo i sul'fatnogo komponentov v glinistykh i sil'vinitovykh porodakh Pripyatskogo solyanogo basseyna. Dokl. AN BSSR 1960, 4, 213-215. (In Russian)

74. Shcherbina, V.N. O vodorastvorimykh komponentakh solyanykh glin Starobinskogo mestorozhdeniya. Dokl. AN BSSR 1963, 7, 772-774. (In Russian)

75. Ivanov, A.A.; Levitskiy, Y.F.; Bayazitov, S.K.; Banchenko, M.S. Geologiya i usloviya formirovaniya Starobinskogo mestorozhdeniya kaliynykh soley v Belorussii. Tr. VSEGEI N. Ser. 1961, 68, 3-75. (In Russian)

76. Lupinovich, Y.I.; Tikhonov, S.A. K kharakteristike sostava fraktsii men'she 0,001 mm galopelitov kaliynykh gorizontov Starobinskogo mestorozhdeniya. In Stratigrafiya, Litologiya i Poleznye Iskopaemye BSSR; Nauka i tekhnika: Minsk, USSR, 1966; pp. 190-201. (In Russian)

77. Lyakhovich, O.K. Veshchestvennyy sostav galopelitov Starobinskogo mestorozhdeniya. In Geologiya $i$ Petrografiya Kaliynykh Soley Belorussii; Nauka i tekhnika: Minsk, USSR, 1969; pp. 301-332. (In Russian)

78. Zaytseva, N.V. Rentgenostrukturnaya kharakteristika solyanykh glin Starobinskogo mestorozhdeniya kaliynykh soley. Byul. Nauch.-Tekhn. Inform. 1966, 2, 31-35. (In Russian)

79. Rasskazov, A.A. Mineraly Glin Kalienosnykh Otlozheniy (Rayon Starobinskogo Mestorozhdeniya); Nauka: Moskva, USSR, 1984. (In Russian)

80. Rasskazov, A.A. Tufogennye gliny i vozmozhnosti ikh ispol'zovaniya dlya differentsirovaniya solenosnykh obrazovaniy. In Osadochnye Porody i Rudy; Naukova dumka: Kiev, USSR, 1978; pp. 177-185. (In Russian)

81. Eroshina, D.M. Geologiya, Usloviya Formirovaniya i Kalienosnost' Solenosnoy Tolshchi Severo-Zapadnoy Chasti Pripyatskoy Vpadiny; Minsk, USSR, 1969. (In Russian)

82. Shaydetskaya, V.S. Mineralogo-geokhimicheskie osobennosti devonskoy kamennoy soli severo-zapadnoy chasti Dneprovsko-Donetskoy vpadiny. In Geokhimicheskie Zakonomernosti Formirovaniya Galogennykh Otlozheniy; IGiG SO AN SSSR: Novosibirsk, USSR, 1983; pp. 62-63. (In Russian)

83. Mossman, D.J.; Delabio, R.N.; Mackintosh, D. Mineralogy of clay marker seams in some Saskatchewan potash mines. Can. J. Earth Sci. 1982, 19, 2126-2140. [CrossRef]

84. Pastukhova, M.V. Autigennye mineraly v khemogenno-terigennykh porodakh Tuz-Tagskoy solenosnoy tolshchi. Litol. Polezn. Iskop. 1965, 1, 31-52. (In Russian)

85. Lounsbury, R.W. Clay mineralogy of the Salina Formation, Detroit, Michigan. In Symposium on Salt; Northern Ohio Geological Society: Cleveland, OH, USA, 1963; pp. 56-63.

86. Bodine, M.W., Jr.; Fernalld, T.H.; Standaert, R.R. The talk-quartz association in marine evaporite (abs.). Trans. Am. Geophys. Union 1973, 54, 487.

87. Bodine, M.W., Jr.; Standaert, R.R. Chlorite and illite compositions from Upper Silurian rock salt, Retsof, New York. Clays Clay Miner. 1977, 25, 57-71. [CrossRef]

88. Kolosov, A.S.; Pustyl'nikov, A.M.; Moshkina, I.A.; Mel'nikova, Z.M. Tal'k v kembriyskikh solyakh Kansko-Taseevskoy vpadiny. Dokl. AN SSSR 1969, 185, 174-178. (In Russian)

89. Pisarchik, Y.K. Novye dannye o sostave glinistogo veshchestva karbonatno-galogennykh otlozheniy nizhnego kembriya Irkutskogo amfiteatra. Mater. VSEGEI N. Ser. 1956, 1, 92-99. (In Russian)

90. Iaremchuk, I.; Tariq, M.; Hryniv, S.; Vovnyuk, S.; Meng, F. Clay minerals from rock salt of Salt Range Formation (Late Neoproterozoic-Early Cambrian, Pakistan). Carbonates Evaporites 2017, 32, 63-74. [CrossRef]

91. Pustyl'nikov, A.M. Glinistye, Khemo- i Biokhemogennye Porody: Metodicheskaya Razrabotka Dlya Prakticheskikh Zanyatiy po Kursu petrografiya Osadochnykh Porod; Novosibirsk State University: Novosibirsk, USSR, 1992. (In Russian)

92. Wójtowicz, A.; Hryniv, S.P.; Peryt, T.M.; Bubniak, A.; Bubniak, I.; Bilonizhka, P.M. K/Ar dating of the Miocene potash salts of the Carpathian Foredeep (West Ukraine): Application to dating of tectonic events. Geol. Carpath. 2003, 54, 243-249.

93. Hryniv, S.P.; Dolishniy, B.V.; Khmelevska, O.V.; Poberezhskyy, A.V.; Vovnyuk, S.V. Evaporites of Ukraine: A review. Geol. Soc. Spec. Publ. 2007, 285, 309-334. [CrossRef]

94. Peryt, T.M.; Hryniv, S.P.; Anczkiewicz, R. Strontium isotope composition of Badenian (Middle Miocene) Ca-sulphate deposits in West Ukraine: A preliminary study. Geol. Quart. 2010, 54, 465-476.

95. Droste, J.B. Clay mineral composition of evaporite sequences. North Ohio Geol. Soc. Mon. 1963, 1, 47-54. 
96. McCaffrey, M.A.; Lazar, B.; Holland, H.D. The evaporation path of seawater and the coprecipitation of Br and K with halite. J. Sediment. Petr. 1987, 57, 928-937.

97. Bilonizhka, P.; Iaremchuk, I.; Hryniv, S.; Vovnyuk, S. Clay minerals of Miocene evaporites of the Carpathian Region, Ukraine. Biul. Państw. Inst. Geol. 2012, 449, 137-146.

98. Yarzhemskaya, E.A. Veshchestvennyy sostav galopelitov. Tr. VNIIG 1954, 29, 260-314. (In Russian)

99. Yaremchuk, Y. Zalezhnist' asotsiatsiy hlynystykh mineraliv v neohenovykh evaporytakh Karpat·s'koho rehionu vid kontsentratsiyi rozsoliv solerodnykh baseyniv. Heol. Heokhim. Horyuch. Kop. 2012, 3-4, 119-130. (In Ukrainian)

100. Drits, V.A.; Kossovskaya, A.G. Glinistye Mineraly: Smektity, Smeshanosloynye Obrazovaniya; Nauka: Moskva, USSR, 1990. (In Russian)

101. Robinson, D.; Schmidt, S.T.; Santana de Zambora, A. Reaction pathways and reaction progress for the smectite-to-chlorite transformation: Evidence from hydrothermally altered metabasites. J. Metamorph. Geol. 2002, 20, 167-174. [CrossRef]

102. Schiffman, P.; Staudigel, H. The smectite to chlorite transition in a fossil seamount hydrothermal system: The Basement Complex of La Palma, Canary Islands. J. Metamorph. Geol. 1995, 13, 487-498. [CrossRef]

103. Strakhov, N.M. Osnovy Teorii Litogeneza (Zakonomernosti Sostava i Razmeshcheniya Aridnykh Otlozheniy); AN USSR: Moskva, USSR, 1962. (In Russian)

104. Petrova, N.S.; Shablovskaya, R.K.; Vysotskaya, M.S. Tufogennye glinistye porody kalienosnykh i nadsolevykh otlozheniy Pripyatskogo progiba. In Novye Dannye po Geologii Solenosnykh Basseynov Sovetskogo Soyuza; Nauka: Moskva, USSR, 1986; pp. 58-66. (In Russian)

105. Ronov, A.B. Osadochnaya Obolochka Zemli; Nauka: Moskva, USSR, 1980. (In Russian)

106. Lowenstein, T.K.; Hardie, L.A.; Timofeeff, M.N.; Demicco, R.V. Secular variation in seawater chemistry and the origin of calcium chloride basinal brines. Geology 2003, 31, 857-860. [CrossRef]

107. Yaremchuk, Y.V. Hlynysti mineraly evaporytiv fanerozoyu ta yikhnya zalezhnist' vid stadiyi z hushchennya rozsoliv i khimichnoho typu okeanichnoyi vody. In Suchasni Probl. Litolohiyi Osadovykh Baseyniv Ukrayiny Ta Sumizhnykh Teryt.; Instytut Heolohichnykh Nauk NANU: Kyiv, Ukraine, 2010; Volume 3, pp. 107-115. (In Ukrainian)

108. Yaremchuk, Y.V.; Vovnyuk, S.V.; Hryniv, S.P. The pecularities of high-magnesium clay minerals occurrence in Phanerozoic evaporite formation. Geodynamics 2020, 28, 52-61. [CrossRef]

109. Garrels, R.M.; Christ, C.L. Solutions, Minerals, and Equilibria; Harper \& Row: New York, NY, USA, 1965.

110. Lomova, O.S. Palygorskity i sepiolity kak indikatory geologicheskikh obstanovok. Tr. GIN 1979, 336, 1-180. (In Russian)

111. Jones, B.F.; Galán, E. Sepiolite and palygorskite. Rev. Mineral. Geochem. 1988, 19, 631-674.

112. Murakami, T.; Sato, T.; Inoue, A. HRTEM evidence for the process and mechanism of saponite-to-chlorite conversion through corrensite. Am. Mineral. 1999, 84, 1080-1087. [CrossRef]

113. Beaufort, D.; Baronnet, A.; Lanson, B.; Meunier, A. Corrensite: A single phase or a mixed-layer phyllosilicate in the saponite-to-chlorite conversion series? A case study of Sancerre-Couy deep drill hole (France). Am. Mineral. 1999, 82, 109-124. [CrossRef]

114. Rateev, M.A. Autigennoe glinoobrazovanie pri vulkanogenno-osadochnom litogeneze. In: Osadkoobrazovanie i poleznye iskopaemye vulkanicheskikh oblastey proshlogo. Tr. GIN 1968, 112, 209-242. (In Russian)

115. Millot, G. Geology of Clays: Weathering, Sedimentology, Geochemistry; Springer: New York, NY, USA, 1970.

116. Kovalevich, V.M.; Vovnyuk, S.V. Vekovye variatsii khimicheskogo sostava rassolov morskikh evaporitovykh basseynov i vod Mirovogo okeana. Geol. i Polezn. Iskop. Mirovogo Okeana 2010, 4, 45-61. (In Russian)

Publisher's Note: MDPI stays neutral with regard to jurisdictional claims in published maps and institutional affiliations.

(C) 2020 by the authors. Licensee MDPI, Basel, Switzerland. This article is an open access article distributed under the terms and conditions of the Creative Commons Attribution (CC BY) license (http://creativecommons.org/licenses/by/4.0/). 